Canadian

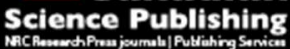

Environmental Reviews Dossiers environnement

\title{
On the integration of ecological and physiological variables in polar bear toxicology research: a systematic review
}

\begin{tabular}{|c|c|}
\hline Journal: & Environmental Reviews \\
\hline Manuscript ID & er-2016-0118.R2 \\
\hline Manuscript Type: & Review \\
\hline Date Submitted by the Author: & 20-Jun-2017 \\
\hline Complete List of Authors: & $\begin{array}{l}\text { Bechshoft, Thea; University of Alberta, } \\
\text { Derocher, Andrew; University of Alberta } \\
\text { Viengkone, Michelle; University of Alberta } \\
\text { Routti, Heli; Norsk Polarinstitutt } \\
\text { Aars, Jon; Norsk Polarinstitutt } \\
\text { Letcher, Robert; Carleton University } \\
\text { Dietz, Rune; Aarhus Universitet Nationalt Center for Miljo og Energi } \\
\text { Sonne, Christian; Aarhus Universitet Nationalt Center for Miljo og Energi } \\
\text { Jenssen, Bjorn; Norges teknisk-naturvitenskapelige universitet } \\
\text { Richardson, Evan; Environment and Climate Change Canada } \\
\text { Lunn, Nicholas; Environment and Climate Change Canada }\end{array}$ \\
\hline Keyword: & Bibliometrics, ecology, polar bear, systematic review, toxicology \\
\hline
\end{tabular}


1 On the integration of ecological and physiological variables in polar bear toxicology

2 research: a systematic review

3 Bechshoft $\mathrm{T}^{1,}$, Derocher $\mathrm{AE}^{1}$, Viengkone $\mathrm{M}^{1}$, Routti $\mathrm{H}^{2}$, Aars $\mathrm{J}^{2}$, Letcher $\mathrm{RJ}^{3}$, Dietz $\mathrm{R}^{4}$, Sonne

$4 \mathrm{C}^{4}$, Jenssen $\mathrm{BM}^{4,5,6}$, Richardson $\mathrm{E}^{7}$, Lunn $\mathrm{NJ}^{8}$

5

$6{ }^{1}$ Department of Biological Sciences, University of Alberta, Edmonton, AB T6G 2E9, Canada

$7 \quad{ }^{2}$ Norwegian Polar Institute, Fram Center, 9296 Tromsø, Norway.

$8 \quad{ }^{3}$ Ecotoxicology and Wildlife Health Division, Science and Technology Branch, Environment

9 and Climate Change Canada, National Wildlife Research Centre, Carleton University, Ottawa,

10 Ontario, K1A 0H3, Canada

$11{ }^{4}$ Department of Bioscience, Arctic Research Centre (ARC), Aarhus University,

12 Frederiksborgvej 399, 4000 Roskilde, Denmark

$13{ }^{5}$ Department of Biology, Norwegian University of Science and Technology, 7491 Trondheim,

14 Norway

$15{ }^{6}$ Department of Arctic Technology, University Centre in Svalbard, P.O. Box 156 N-9171

16 Longyearbyen, Norway

$17{ }^{7}$ Wildlife Research Division, Science and Technology Branch, Environment and Climate

18 Change Canada, Winnipeg, Manitoba, R3C 4W2

$19{ }^{8}$ Wildlife Research Division, Science and Technology Branch, Environment and Climate

20 Change Canada, Biological Sciences Building, University of Alberta, Edmonton, Alberta, T6G

21 2E9, Canada 
$22 *$ Corresponding author: Thea Bechshoft, Department of Biological Sciences, University of

23 Alberta, Edmonton, AB T6G 2E9, Canada. Telephone: +4526351268, Fax: N/A, Email:

24 thea.bechshoft@,ualberta.ca/thea.bechshoft@gmail.com

25

26 Word count: 13.759 words (incl. references, tables, figures, and Supporting Information). 


\section{Abstract}

28 Ecotoxicology evolved as a scientific field as awareness of the unintended effects of anthropogenic pollutants in biota increased. Polar bears (Ursus maritimus) are often the focus of Arctic contaminant exposure studies because they are apex predators with high contaminant loads. While early studies focused on describing and quantifying pollutants, present-day polar

32 bear toxicological papers often incorporate ecological variables. This systematic literature review investigates the ecological and physiological variables that have been integrated in such studies.

34 The systematic literature search resulted in 207 papers, published between 1970-2016.

35 Representation of each of the 19 polar bear subpopulations varied from 0 to 72 papers; East

36 Greenland, Barents Sea, Southern Beaufort Sea, and Lancaster Sound had the most published

37 research, with over 30 papers each. Samples were collected between 1881 and 2015, primarily

38 from harvested bears (66\%); most from the 1990s and 2000s. Adipose tissue, liver, and blood

39 were the most common tissues examined, and mean number of bears analyzed per paper was 76

40 (range 1-691). Papers investigating temporal trends did so using a mean sample of 61 bears over

41 a 6-year period.

42 The frequency with which ecological and physiological variables were integrated into

43 toxicological papers varied. Age and/or sex was the only ecological variable(s) considered in

$4451 \%$ of papers. Further, a total of $37 \%$ of the papers included in the review investigated

45 physiological effects in relation to contaminant concentrations. 98\% dealt with contaminant

46 exposure at the individual level, leaving population level effects largely unstudied. Solitary

47 subadult and adult polar bears were included in $57 \%$ and $79 \%$ of the papers, respectively.

48 Younger bears were included in fewer papers: yearlings in 20\% and cubs-of-the-year in 13\%.

49 Only $12 \%$ of the papers examined reproduction relative to contaminants. Finally, body condition 
50 was included in $26 \%$ of the research papers, whereas variables related to polar bear diet were 51 included in $\leqslant 9 \%$.

52 Based on our findings, we suggest future polar bear toxicology studies increase sample

53 sizes, include more ecological variables, increase studies on family groups, and increase the

54 applicability of studies to management and conservation by examining pollution effects on

55 reproduction and survival.

56

57 Key words:

58 Bibliometrics, contaminants, ecology, polar bear, systematic review, toxicology 
60

61

62

63

64

65

66

67

\section{Background}

Ecotoxicology is the multidisciplinary study of chemical contaminants in the environment and their effects on biota (Newman, 2010), including aspects of ecology, toxicology, chemistry, physiology, immunology, endocrinology, developmental biology, and genetics. Ecology and toxicology both consider multiple scales in three primary areas: biological scales of organization, time, and space (AMAP, 1998, Graham et al., 2013). Ecology was first defined as the "relation of the animal both to its organic as well as inorganic environment" (Haeckel, 1866) and later as "interactions that determine the distribution and abundance of organisms" (Krebs, 1972).As such, ecology encompasses a range of disciplines including physiology, evolution, genetics, behavior, energetics, population dynamics, and relationships with other species. In contrast, toxicology focuses on the detection, properties, exposure concentrations, and effects of toxic compounds (Newman, 2010). Ecological and toxicological aspects can be applied to any level of biology, from cell to biosphere. However, in wildlife studies, ecology typically focuses on the individual, population, or species, whereas toxicology usually focuses on the molecular, cellular, and organ level of the individual. Thus, ecological studies in wildlife often begin at the individual level, which is where toxicology studies usually end (AMAP, 1998, Chapman, 2002).

Furthermore, wildlife ecology examines the larger-scale effects (Johnson, 1980, Mayor et al., 2009), while toxicology tells us that variables are changing, but rarely what the larger-scale effects and impacts may be. Taking an interdisciplinary approach by combining the two fields provides greater insight into factors influencing the bioaccumulation and toxicological effects of pollutants in wildlife. 
82 Anthropogenic chemicals in the environment predate concerns of their effects on wildlife or

83 humans. For example, polychlorinated biphenyls (PCBs) were first synthesized in 1881 and

84

85

while their use in industry emerged about 50 years later (Cairns and Siegmund, 1981), they were not reported as persistent and bioaccumulated contaminants in biota until 1966 (Jensen, 1966).

Generally, other environmental pollutants have a shorter history and new, emerging ones are frequently discovered, including in the Arctic (Trumble et al., 2012, Dietz et al., 2013a, Gebbink et al., 2016). Persistent organic pollutants (POPs) cover a diversity of compounds including legacy compounds (defined as those that remain in the environment long after they were introduced) such as PCBs, DDTs, and chlordanes, as well as new chemicals of emerging concern (CECs), such as brominated flame retardants (BRFs) and some current-use pesticides (Bidleman et al., 2010, Butt et al., 2010, Warner et al., 2010, Gebbink et al., 2016, AMAP, In review). Heavy metals, especially methylmercury (MeHg), are another group of toxic compounds of concern in Arctic biota (Eaton and Farant, 1982, Norstrom et al., 1986, Dietz et al., 2013b).

Ecotoxicology evolved as a scientific field in the 1950s and 1960s as the emergence of unintended effects of anthropogenic chemicals in biota became apparent (Rattner, 2009, Newman, 2010). Although DDT had been detected in wildlife in the 1950s (Rattner, 2009), it was eggshell thinning in birds of prey that provided evidence of the detrimental effects of environmental pollution (Ratcliff, 1967). The first Arctic toxicological papers were published in the 1970-80s at which time long-range transport of pollutants became apparent (Kerr, 1979, Barrie et al., 1992). The first paper on chlorinated organic chemicals in an Arctic marine mammal was published by Holden (1970), who detected PCBs, DDT, and dieldrin in ringed seals (Pusa hispida). More detailed reports on PCBs and DDT-related compounds in the Arctic 
105 were published in the early 1970s on ringed seal and beluga whales (Delphinapterus leucas)

106 (Addison and Brodie, 1973, Addison and Smith, 1974, Clausen et al., 1974). Studies on heavy

107 metals in the Arctic occurred about the same time on harp seals (Pagophilus groenlandicus) and

108 hooded seals (Cystophora cristata) (Sergeant and Armstrong, 1973). The first paper on POPs in 109 polar bears (Ursus maritimus) was published by Bowes and Jonkel (1975), who reported high

110 concentrations of PCBs in the bears' milk. Similar to legacy contaminants, heavy metals were

111 first quantified in polar bears several decades ago (Eaton and Farant, 1982, Norstrom et al.,

112 1986). Once it became clear that high concentrations of these compounds were found in polar

113 bears, they became a focal species for studies of contaminant exposure in the Arctic.

115 Publications in polar bear toxicology have been increasing since the 1970s (Fig. 1). Expanding 116 our knowledge on the exposure and effects of contaminants on polar bears is of particular 117 concern because they are apex predators with a high lipid diet and, as such, carry high loads of 118 contaminants due to biomagnification (Atwell et al., 1998, Hobson et al., 2002). POPs are 119 generally lipophilic compounds as exemplified by PCBs and PBDEs, as well as some forms of 120 metals such as methylmercury (AMAP, 1998, Sonne, 2010, McKinney et al., 2011, Dietz et al., 121 2013b). Although subpopulation specific, polar bears are at risk as a consequence of the effects 122 of climate change (Stirling and Derocher, 2012), pollution (Sonne, 2010), harvest (Taylor et al., 123 2006), and the synergistic effects of these stressors (Holmstrup et al., 2010, Hooper et al., 2013, 124 Jenssen et al., 2015). Since polar bears are harvested for human consumption (Ostertag et al., 1252009 , Sonne et al., 2013b), knowledge of contaminants and their effects on polar bears may also 126 aid our understanding of the extent and nature of their potential effects in humans. 
127 Collecting data on widely dispersed and solitary wildlife species, such as polar bears, is

128 challenging. Thus, there is a need to coordinate and optimize available resources to maximize the

129 scientific output contributing to the conservation of the species (Vongraven et al., 2012, Jenssen

130 et al., 2015, Patyk et al., 2015). Despite identification of environmental contaminants as a key

131 threat to polar bears (Amstrup et al., 2007, Patyk et al., 2015), there has been no systematic

132 overview of their ecotoxicology across all subpopulations.

133

134 The primary aim of this systematic review was to examine the integration of ecological and 135 physiological variables in the polar bear toxicology peer-reviewed literature. The secondary aim 136 was to identify knowledge gaps within the field of polar bear ecotoxicology and provide 137 recommendations on how to fill those gaps through future research within the field.

138 The systematic review process

A systematic review of peer-reviewed literature was performed based on searches in the

141 comprehensive database Web of Science ${ }^{\mathrm{TM}}$ (Reuters, 2016). "All databases" were searched (see

142 Table S1 for an overview of the included publication databases) using polar bear- and

143 contaminant-related search terms to generate an initial list of potential papers. This list was then

144 refined, retaining papers where polar bears were the focal species. The date of publication was

145 unrestricted but only peer-reviewed papers in English were included. The resulting papers were

146 then divided into two categories:

147 - research papers - original contaminant exposure or toxicological studies (e.g., Derocher

148 et al., 2003, Basu et al., 2009) or 
- review papers - overview of already published contaminant exposure or toxicological studies (e.g., Letcher et al., 2010, McKinney et al., 2015).

Please note that in this paper, "toxicology" and "toxicological" encompasses studies of contaminant exposure as well as studies of toxicology.

A number of biological, ecological, and contaminant related variables were registered for each paper included in the systematic review (see Table 1 for core ecological variables and Table S2, full list of all variables and their definitions). Refining the list of papers from the initial literature search (as described above) and registering the variables (Table S2) on those papers that were included in the review was done by co-author M. Viengkone.

To assess number of polar bear toxicology research publications relative to other species, we created an index of such publications for a selection of marine and terrestrial mammal species. The index was created using the raw, unfiltered results from literature searches for each species in connection with the contaminant-related search terms outlined above.

\section{Search terms}

Two "TOPIC" search terms were combined using the Boolean operator "AND”. The asterisk (*) indicated wildcard truncation in the specific terms.

• " polar bear" OR "ursus maritimus" OR "thalarctos maritimus"

- pollut* OR contamin* OR metal* OR flame* OR PCB* OR organo* OR cadmium* OR mercur* OR lead* OR pestic* OR PFOS OR PFAS OR PFOA OR PFCA OR PFC* OR hydrox* OR OH-* OR bromin* OR perfluor* OR fluor* OR chlor* OR halogen* OR legacy OR emerg* OR metabolit* 


\section{Statistical analyses}

172 Linear regression analyses were used to investigate temporal relationships in number of authors

173 and number of bears sampled in research papers. In addition, a Kruskal-Wallis rank sum test was

174 used to examine temporal patterns in polar bear sample collection. Statistical analyses were

175 conducted using Microsoft Excel 2010. Results were considered statistically significant at $\mathrm{p} \leq$ 1760.05.

177 Literature review findings and considerations

\section{Literature}

181 The literature search was conducted on August 17, 2016 and yielded 207 publications published 182 between 1970 and 2016 (Fig. 1); 176 research papers, 27 reviews, and 4 papers that were both 183 research and review (i.e., Henriksen et al., 2001, Sonne et al., 2009a, Dietz et al., 2015, Pavlova 184 et al., 2016). These four papers were included in both the research and the review paper 185 categories. Research papers were published in 43 different journals, with 19\% published in 186 Environmental Science \& Technology and 16\% in Science of the Total Environment. Review 187 papers were published in 16 different journals, with $42 \%$ in Science of the Total Environment. 188 The index of toxicology publications for a selection of marine and terrestrial mammal species 189 (Fig. 2) showed that polar bears, along with beluga whales, were one of the more well-published 190 Arctic marine mammal species within this field and had a similar number of published papers to 191 mink (Mustela lutreola and Neovison vison), which are often used as a mammal model species in 
192 toxicology studies (Wang et al., 2014, Folland et al., 2016, Pavlova et al., 2016). Ringed seals, 193 the main prey species of polar bears (Thiemann et al., 2008), were also well studied.

195 There is a temporal trend to include more authors on publications in complex, collaborative 196 fields of research such as toxicology (Subramanyam, 1983, Mindeli and Markusova, 2015).

197 While this trend was not found in the review papers $\left(1992-2016\right.$; Fig. $3 a ; F_{1,29}=2.00, p=0.17, r^{2}$ $198=0.06)$, there was an increasing trend towards more authors for research papers published 19701992016 (Fig. 3b; $F_{1,178}=48.36, p<0.001, r^{2}=0.21$ ). Although the number of authors per paper 200 varies between natural science fields, the 7-8 authors we found to be the average for polar bear 201 toxicology papers (research as well as review) is at the higher end of the range (Newman, 2001). 202 International collaboration is common in polar bear toxicology (Table 2). First authors based at 203 institutions within Canada and Denmark have been the most prolific followed by Norway and the 204 United States (Table 2). Greenland and Russia are largely represented as coauthors on research 205 publications with first authors from other countries. Low contributions from these two countries 206 may be related to our choice of search engine and focus on publications in English only. The low 207 number of papers from Greenland reflects that most research on Greenland polar bear 208 subpopulations was conducted by Denmark-based scientists.

210 The ratio of polar bear toxicology research papers to review papers was 6:1 (Fig. 1). The high 211 frequency of review papers highlights two aspects about polar bear toxicology: 1) it is a complex 212 field encompassing a large number of chemicals and ecological variables, 2) due to the often 213 limited sample size, each study only considered a limited number of ecological variables.

214 Review papers present a means to reduce these restrictions by integrating insights from 
215 individual papers, thereby facilitating incorporation and interpretation of a wider range of

216 variables.

217 Toxicology

218

219 Samples

220 Results of exposure and toxicology research have been published for all recognized polar bear

221 subpopulations (mean \pm S.E.: $21 \pm 4$ papers/subpopulation, range: 0-72), except the Arctic Basin

222 (Fig. 4a-b; IUCN PBSG, 2010). East Greenland, Barents Sea, Southern Beaufort Sea, and

223 Lancaster Sound subpopulations were the most studied with $>30$ papers each. Toxicological

224 research has been a priority in East Greenland and Barents Sea because of high contaminant

225 loads (AMAP, 1998, Norstrom et al., 1998, Letcher et al., 2010, Sonne, 2010, Dietz et al., 2015).

226 The number of polar bears harvested varies widely across Canadian subpopulations (IUCN

227 PBSG, 2010) and the access to samples from a large harvest in Lancaster Sound may have

228 facilitated this research (Vongraven et al., 2012). Finally, the high number of papers including

229 the Southern Beaufort Sea subpopulation is likely due to it being a shared subpopulation with

230 publications from both Canada and USA, its long history of population assessment, and

231 monitoring in relation to hydrocarbon exploration (Amstrup, 2000, Stirling, 2002).

232

For those subpopulations where research has been undertaken, Kane Basin, Laptev Sea,

233 Kara Sea, and Norwegian Bay were the least studied ( $<10$ papers each), likely because they are

234 less accessible (Fig. 4a) and have low or no harvest (Vongraven et al., 2012). Limited resources

235 and varying priorities for the different subpopulations affect research intensity. However,

236 ecotoxicological studies should optimally form part of polar bear monitoring and research

237 programs, in particular due to the adverse interactions that exist between climate change and 
238

239

240

241

242

243

244

245

246

247

248

249

250

251

252

253

254

255

256

257

258

259

260

contaminants (AMAP, 2011, Jenssen et al., 2015), but also due to the direct sub-lethal effects that contaminant exposure may have on the bears' reproduction and health (Letcher et al., 2010, Sonne, 2010, Dietz et al., 2015, Sonne et al., 2015). Without the ability to include ecologically relevant data as input in predictive toxicological models, the effects of potentially important variables influencing the health status and survival of polar bears is missing (also see Atwood et al., 2016).

Polar bears were the only species studied in $65 \%$ (117) of research papers, whereas in $35 \%(63)$, they were studied along with other species including fish, turtles, pinnipeds, cetaceans, sled dogs, and humans (e.g., Giesy and Kannan, 2001, Sonne, 2010). The mean number of polar bears sampled per paper was 76 (S.E. $=8.4$, range: $1-691)$, with a positive trend in number of samples/paper over time that approached significance (Fig. 5; $F_{1,171}=3.16, p=0.08, r^{2}=0.02$ ). The three papers with the largest number of samples included museum specimens (range $\mathrm{n}=$ 510-691; Sonne et al., 2007b, Bechshoft et al., 2008, Bechshoft et al., 2009). Larger sample sizes allow for parsing of data into homogenous groups (e.g., sex/age categories), while maintaining statistical robustness. It also facilitates investigation of interactions between variables without overfitting or otherwise compromising the data analyses (Hair et al., 2006, Crawley, 2007). Toxicological papers with small sample sizes (e.g., $\mathrm{n} \leq 30)$ were often exploratory (e.g., Sacco, 2005, Verreault et al., 2006), experimental (e.g., Lie et al., 2004, Lie et al., 2005), or focused on new analytical method development for chemical contaminants and biomarker endpoints of effects pathways and mechanisms (e.g., Letcher and Norstrom, 1995, Simon et al., 2011).

Developing new methods using only a small number of samples is advantageous with regard to cost, time, and optimal usage of the limited tissue samples available. The number of polar bear 
261 samples available for toxicological research depends on a number of factors such as

262 subpopulation(s) investigated and sampling methods. The origin of samples used in the 180

263 papers were 66\% (119) harvested bears, 25\% (45) live bears, 6\% (10) both harvested and live

264 bears, and 3\% (6) unknown. The most common tissues examined were adipose tissue, liver, and

265 blood, incorporated in 40\% (72), 38\% (69) and 26\% (46) of the papers, respectively (Fig. 6).

266 While tissue samples such as kidney, liver, and reproductive organs are useful in determining

267 histopathological toxicological and functional endpoints (Beland et al., 1993, Bergman, 1999,

268 Letcher et al., 2010, Sonne, 2010, Gabrielsen et al., 2015), they are only available from dead

269 animals. As climate change induced habitat loss and, to some degree, pollution are expected to

270 have increasingly adverse effects on the abundance of polar bears, the availability of samples,

271 especially invasive samples such as e.g. liver and kidney tissue, may decline long-term (Amstrup

272 et al., 2007, Derocher et al., 2013). Thus, it is increasingly important to establish relationships

273 between toxicological results based on invasive versus minimally- or non-invasive samples. Such

274 samples include those that can be collected without direct contact with the animal, e.g., fecal

275 samples (Iversen et al., 2013) or hair samples collected using hair snags (de Groot et al., 2013).

276 Born et al. (1991) found concentrations of mercury in polar bear hair to be positively correlated

277 to mercury concentrations in muscle, liver, and kidney tissue. However, the types of samples and

278 how they are collected will be dependent on the research objectives.

279

280 Temporally, the research papers were based on samples collected from 1881 to 2015, with the

281 1990s and 2000s being more prevalent (Fig. 7; Kruskal-Wallis rank sum test, H=7.75, p <

282 0.01). Ten papers analyzing hair or bones from museums spanned $>100$ years (e.g., Horton et

283 al., 2009, Sonne et al., 2013a). Including these 10 papers, the mean time span covered was 12 
284 years $($ S.E. $=2.1$; range 1-119), while excluding them reduced the mean to 6 years $($ S.E. $=0.8$, 285 range 1-71). Six years is a brief period considering the interannual variation in ecological as well 286 as contaminant-related variables and the lifespan of polar bears (see Riget et al., 2010, Riget et 287 al., 2011). Further, the years included in these time spans were not necessarily contiguous. Many 288 papers listed only a range of years within which the bears were sampled, while 9 papers included 289 no information of sampling year(s). Removing the 10 papers where the time series $>100$ years, 290 the mean sample size was 61 bears $($ S.E. $=6.0$, range $1-378)$ or only 10 individuals/year, which 291 is at the low end of the 10-25 annual samples recommended for monitoring time trends of PCBs 292 in polar bears (Henriksen et al., 2001). Determining adequate annual sample size depends on 293 degree of interannual variability, statistical tests used, number of years of sampling, and 294 demographic composition of the sample (Bignert et al., 2004). While a sample of 10 bears/year 295 may seem numerically reasonable, samples are often a mix of bears of different age- and sex296 classes, reproductive status, body condition, geographical location, and contaminant load, which 297 are all important factors that can affect exposure and physiology (Polischuk et al., 2002, Letcher et al., 2010, Sonne, 2010). Therefore, the annual sample size for any one demographic group is 299 often significantly smaller. Coordinated sampling across years and polar bear subpopulations 300 could help address sample size issues and provide statistical power to temporal studies.

302 Twenty-eight percent (50) of research papers reported on the analysis of tissues collected in one 303 season only: 19\% spring (34; March-May), 4\% summer (7; June-August), 3\% fall (5; September304 November), and 2\% winter (4; December-February). The remaining papers incorporated samples 305 collected in two $(16 \%, 28)$, three $(7 \%, 13)$, or all four $(6 \%, 10)$ seasons. Two papers $(1 \%)$ 306 combined spring samples with samples of unknown season, while the remaining 43\% (77) were 
307 entirely based on samples of unknown collection season. Overall, regardless of number of

308 seasons represented, spring was the most prevalent sampling season (44\% [79]), compared to 309 summer $18 \%(32)$, fall 21\% (38), and winter $21 \%$ (38). For most polar bear subpopulations, 310 spring was the most prevalent sampling period because it is the season with the most harvest, the 311 stable sea ice facilitates sampling of bears, and all sex/age classes are accessible during this time. 312 Although season can have a significant influence on polar bear contaminant load (Polischuk et 313 al., 2002, Dietz et al., 2004, Dietz et al., 2007), it was rarely considered in polar bear toxicology 314 studies.

\section{Contaminants}

317 Chlorinated compounds and pesticides were included in 55\% (99) and 41\% (74) of the polar bear 318 toxicology papers, respectively. Heavy metals, metabolites, and brominated and fluorinated 319 compounds were each included in 17-28\% (30-50) of the papers (Fig. 8). Although the choice of 320 specific compounds studied is rarely explained, the most commonly investigated are those 321 included in the 2001 Stockholm Convention; a continuously updated, global treaty with the 322 purpose of protecting humans and the environment against persistent organic pollutants (UNEP, 323 2001, Muir and Howard, 2006, Hung et al., 2016). Our understanding of contaminant 324 metabolites is still rudimentary. As our knowledge of the relationship between exposure and 325 effects of parent compounds and metabolites increases, metabolites may be included in more 326 studies. However, the study of metabolites and other new CECs continues to be challenged by 327 the lack of analytical methods and pure chemical standards (Keith, 1976, Wiener, 2013, Gebbink 328 et al., 2016). 
330 Contaminants in research papers were examined in relation to biology (those listed in Table 3 as 331 well as age and/or sex; see definition under "Effects" in Table S2), space, and time (Fig. 9). Most 332 papers examined either contaminant concentrations $(29 \%, 53)$ or contaminant concentrations and 333 biology $(32 \%, 57)$. However, $67 \%(38)$ of the latter only included age and/or sex in their 334 analyses. Thus, $51 \%(53+38)$ of the papers included no, or only the most basic, biological 335 information on their study animals. One explanation for this could be that the objectives of 336 earlier papers focused on identifying and quantifying contaminants, essential information which

337 formed the educated basis for studies on their effects. However, contaminant concentrations 338 alone tell us little about the toxicity mechanisms and potential adverse effects. Controlled studies 339 in other mammals have shown that even low concentrations of specific contaminants may have 340 physiological effects (Voltura and French, 2000, Martin et al., 2006, Sonne et al., 2009b, Zimmer 341 et al., 2009, Kirkegaard et al., 2010). Further, the potential mixture effects between the hundreds 342 of different contaminants in polar bears requires additional consideration (Letcher et al., 2010, 343 Sonne, 2010, Sonne et al., 2012, Dietz et al., 2015); these effects could furthermore differ 344 depending on whether the exposure is acute or chronic (Chapman, 2002).

346 Of the biological effects that were studied in relation to contaminant concentrations, pathology 347 was the most prevalent (9\%, 17; Table 3). Morphometrics, enzymes, and hormones were each 348 studied in $4-6 \%$ of all papers $(7 \leq n \leq 11)$, whereas immune system, protein levels, reproductive 349 potential, vitamins, receptor levels, and transport proteins each were the focus of $2-3 \%(3 \leq \mathrm{n} \leq$ 3505 ) of the papers. Altogether, 37\% (66) of the papers included in the review investigated 351 biological effects in relation to contaminant concentrations (Table 3). 
353 Notably, 98\% (176) of all papers dealt with contaminant exposure at the individual level. The

354 four exceptions were Bernhoft et al. (1997), who investigated population level effects by

355 assessing the relationship between contaminants and reproductive success in female polar bears,

356 and Sonne et al. (2009a), Dietz et al. (2015), and Pavlova et al. (2016), who all modelled

357 potential for population level effects due to reproductive impairment. Modeling is likely to

358 become increasingly applied in polar bear ecotoxicology to extrapolate individual level studies to 359 the population level.

363 The frequencies with which ecological and physiological variables were integrated into

364 toxicological papers varied (Table 1). Age and sex were the most common: age to nearest month 365 or year was used in $82 \%(148)$ of the papers, whereas sex was used in $72-74 \%$ (130 for males, 366134 for females). Finally, 10.5\% (19) overlapped in that they investigated neither sex nor age in 367 relation to contaminants. Life history traits such as age and sex are primary variables 368 determining vulnerability to contaminant exposure because they reflect the animal's life stage 369 and physiological (dietary) requirements (Thiemann et al., 2008, Diamanti-Kandarakis et al., 370 2009, Letcher et al., 2010, McKinney et al., 2013). Further, inter-sexual differences in diet and 371 hormones influence how a contaminant may affect an individual (Pilsner et al., 2010, Sonne, 372 2010). Bears of unknown sex were included in $14 \%$ of the papers, generally as a smaller 373 percentage $(<15 \%)$ of the total number of individuals (e.g., Routti et al., 2011). In most of the 374 papers where gender was unknown, it was the result of using inadequately labeled, museum 375 specimens (e.g., Sonne et al., 2004). 
377 Solitary subadult and adult polar bears were included in 57\% (102) and 79\% (142) of the papers, 378 respectively. Younger bears were included in fewer papers: yearlings in 20\% (36) and cubs-of379 the-year in $13 \%$ (24). From a conservation perspective, studying contaminants in adult polar 380 bears is relevant to their reproductive success and would include variables such as epigenetics, 381 reproductive organ deformation, and behavior (Sonne et al., 2007a, Pilsner et al., 2010, Jenssen 382 et al., 2015, Sonne et al., 2015). Furthermore, effects of contaminants may reduce survival and 383 thus reproductive output (Derocher et al., 2003, Dietz et al., 2015). However, developing young 384 are more sensitive to the effects of contaminants (Domingo, 1994, Hamlin and Guillette, 2011), 385 while also being subjected to high concentrations via maternal transfer (Bernhoft et al., 1997, 386 Bytingsvik et al., 2012). Given the risk of lifelong consequences (Colborn et al., 1993, Hamlin 387 and Guillette, 2011), dependent and developing young are underrepresented in the polar bear 388 toxicology literature.

Presence of dependent offspring can have a profound influence on maternal contaminant load in 391 polar bears (Lie et al., 2000, Polischuk et al., 2002). In addition, information on reproductive 392 success, including sex, age, and survival of cubs, is essential for population assessments.

393 However, only $12 \%(21)$ of the research papers examined reproduction in relation to 394 contaminants. Lack of linkages to reproduction could be due, in part, to the large number of 395 toxicological papers where samples are collected from harvested animals, which generally 396 excludes family groups because they are protected from harvest (Naalakkersuisut, 2005, Sonne, 397 2010). Data on family groups is more readily obtainable for frequently monitored subpopulations 398 (e.g., Barents Sea, Western Hudson Bay, and Southern Beaufort Sea). Of the papers that 
399 incorporated offspring variables in the contaminant analysis, 9\% (16) included offspring age, $4 \%$

400 (7) offspring sex, and $2 \%$ (4) litter size. In addition to the $12 \%$ of papers that included some

401 measure of reproduction, another 7\% reported on contaminants in dependent young, but without

402 any further statistical analysis (e.g., Dietz et al., 2000, Derocher et al., 2003). Dependent young

403 differ in contaminant exposure and physiological variables such as hormone concentrations, not

404 only from adults, but also due to sex and age (Bernhoft et al., 1997, Oskam et al., 2003, Oskam

405 et al., 2004, Knott et al., 2012, Bechshoft et al., 2016a). Differences in physiological response to

406 contaminants is expected between offspring life stages (e.g., when shifting from milk to solids)

407 as well as between the sexes, as these differ in their endocrine, morphological, and overall

408 physiological profile already at the fetal stage (Derocher et al., 2005, Hamlin and Guillette, 2011,

409 Maekawa et al., 2014).

410

411 The amount of lipophilic contaminants biologically available to a bear is closely linked to its

412 body condition (size of adipose tissue store): the leaner the bear, the higher the contaminant

413 concentration in its blood stream (Polischuk et al., 2002). However, body condition was included

414 in the contaminant analyses in only $26 \%$ (46) of the research papers. In addition, adult female

415 polar bear body condition is related to reproductive success (Derocher et al., 2004, Robbins et

416 al., 2012), indicating a potential link between body condition, contaminant load, and

417 reproductive success. Investigating contaminants in relation to body condition is also interesting

418 in that they are associated with altered metabolism in other species (Voltura and French, 2000,

419 Verreault et al., 2007, van Ginneken et al., 2009), and, as shown in a paper published after and

420 thus not included in our systematic literature review, may have the potential to modulate polar

421 bear energy metabolism (Routti et al., 2016). Finally, measures of polar bear diet were included 
422 in $\leq 9 \%(\leq 17$; Table 3$)$ of the contaminant analyses. As the contaminant concentration and 423 composition in prey species varies widely (McKinney et al., 2010, St Louis et al., 2011, Routti et 424 al., 2012, McKinney et al., 2013), diet information is a variable that warrants further 425 investigation. For example, information on diet could help explain differences in contaminant 426 concentrations between demographic groups such as males and females or subadults and adults.

427 Genetics, size of home range, and climate variables were each examined in $\leq 1 \%(\leq 2$; Table 3$)$

428 of the research papers, while the variable behavior (which in this review is separate from 429 movement, see Table S2) was never used. Given the relationship between these variables and 430 toxicology, they could be an area for future studies. Investigating individual and geographical 431 differences in the animals' exposure to contaminants is a relevant conservation topic (Bickham et 432 al., 2000, Brown et al., 2009). Further, larger home range sizes have been linked to higher 433 contaminant exposures in polar bears (Olsen et al., 2003), while climate variables have been 434 linked to the abundance and behavior of the contaminants in their ecosystem (Derocher et al., 435 2004, AMAP, 2011, Ma et al., 2011). Finally, alteration of behavior caused by contaminant 436 exposure has been observed in other mammals(Clotfelter et al., 2004, Patisaul and Adewale, 437 2009, Zimmer et al., 2009). Therefore, combining contaminant concentration information with 438 behavioral observations of wild polar bears may be useful given that the contaminants can affect 439 vitamin and endocrine levels (Villanger et al., 2011, Bechshoft et al., 2015, Pedersen et al., 2015, 440 Bechshoft et al., 2016b), which in turn may affect behavior. Similarly, a change in feeding 441 behavior could affect contaminant exposure (McKinney et al., 2013, McKinney et al., 2015).

\section{Conclusions and recommendations}

444 Summary: Key knowledge gaps 
445 Although our systematic review of the published literature found polar bears to be one of the

446 better studied Arctic marine mammals in the field of toxicology, few of the papers incorporated

447 variables related to their ecology and physiology (as outlined in Table 1 and Table 3): 51\% of the

448 research papers included merely the most basic of ecological variables in their analysis, while

449 only $37 \%$ of the research papers investigated physiological effects in relation to contaminant

450 concentrations. The increased integration of such variables in exposure and toxicology studies

451 has particular relevance to polar bear conservation given concerns of contaminants as a threat to

452 the species. Vongraven et al. (2012) and Patyk et al. (2015) noted the need for multidisciplinary

453 projects that include a broad range of ecological variables. Our review identified existing

454 knowledge gaps in polar bear ecotoxicology. Based on our findings, we suggest that polar bear

455 researchers consider the following recommendations when designing future ecotoxicology

456 studies:

457

458 (1) Subpopulation(s)

459 While it would be beneficial to have ecotoxicological data for all polar bear subpopulations,

460 logistical restraints require prioritization. Furthermore, the choice of which polar bear

461 subpopulation to focus on will depend on the nature of the scientific questions being

462 investigated. For example, if family group data is required, relying on a hunter harvest will be of

463 little value because family groups are protected from harvest. Similarly, studies on temporal

464 trends would benefit from previous investigations of the variables of interest in the same area.

465 Our recommendation for focal subpopulations in future ecotoxicology studies are all included in

466 those suggested as appropriate for high or medium intensity monitoring under the circumpolar

467 polar bear monitoring framework outlined by Vongraven et al. (2012): Barents Sea, Chukchi 
468 Sea, East Greenland, Northern Beaufort Sea, Southern Beaufort Sea, and Western Hudson Bay

469 (see Table 4 for an overview). Results from disparate subpopulations, differing with regard to

470 ecological data or availability of tissue samples, would complement each other, thereby

471 providing a greater understanding of the relationship between ecology and toxicology.

472

473 (2) Exposure assessments and temporal trends

474 Assessing change in the contaminant exposure of polar bears, or temporal exposure trend studies,

475 would benefit from increased sample set sizes as well as an increase in the range of years

476 covered. Depending on collection protocols, increased use of polar bear specimens from

477 museums as well as those stored in tissue banks would help address both of these problems, and

478 at low cost. In addition, the continued collection and archiving of samples is recommended.

479 Finally, larger and more homogenous sample sizes may allow for the incorporation of additional

480 ecological variables in temporal trend studies.

481

482 (3) Family groups

483 Dependent and developing young are underrepresented in the polar bear toxicology literature.

484 Hence, family groups and dependent young should be included in ecotoxicology studies

485 whenever logistically and ethically possible. If sample size allows, dependent young should be

486 split into sex/age groups before analyses. Furthermore, polar bear ecotoxicological studies

487 should include measures of reproduction (e.g., lactation, number/age/sex/weight/body condition

488 of offspring) in analyses whenever possible. Such detail may be more difficult to incorporate in

489 studies based on hunter-gathered samples, as the harvest is often male biased (Derocher et al., 
490 1997), but should be more readily obtainable in studies based on observational and/or researcher-

491 gathered data.

492

493 (4) Ecological variables

494 Body condition is an essential variable to consider in ecotoxicological studies, especially with

495 respect to lipophilic compounds, and should be among the data collected on all bears, regardless

496 of the sample origin. Developing an understanding of the relationship between various methods

497 of measuring body condition would also be helpful in facilitating inter-study comparisons (Cattet

498 et al., 2002, Stirling et al., 2008, McKinney et al., 2014). Furthermore, we recommend increased

499 incorporation of ecological variables such as diet, climate, reproduction, and survival in

500 ecotoxicological studies. In addition to following up on the existing studies on hormone response

501 and immune function (Bernhoft et al., 2000, Lie et al., 2004, Oskam et al., 2004, Bechshoft et al.,

502 2012, Macbeth et al., 2012, Weisser et al., 2016), hitherto uninvestigated health and immune

503 system variables such as parasitic load may also be of interest in relation to ecotoxicological

504 polar bear studies. Finally, behavior may be an important, yet largely uninvestigated, variable in

505 polar bear ecotoxicological research.

506

507 (5) Conservation implications

508 Essentially all polar bear ecotoxicological data published investigate the impacts of contaminants

509 at the individual level. If ecotoxicology is to be considered in population assessments, results

510 must be applicable at the population level, which could be achieved through meta-analyses (e.g.,

511 Nuijten et al., 2016), modeling, or reviews based on already existing data. In new contaminant 
512 studies, an understanding of population-level effects could be achieved by incorporating more 513 variables directly related to reproduction and survival.

514

515 Polar bear ecotoxicology has helped shape our understanding of the detrimental effects of 516 anthropogenic contaminants in the Arctic. It is our hope that the knowledge gaps identified in 517 this review will influence research planning, thus increasing the research impact, especially with 518 regard to population assessments, management, and conservation of polar bears. 
520 Acknowledgements

521 ArcticNet, Canadian Association of Zoos and Aquariums, Canadian Wildlife Federation,

522 Environment and Climate Change Canada, Hauser Bears, Natural Sciences and Engineering

523 Research Council of Canada, Polar Bears International, Quark Expeditions, the Villum

524 Foundation, and World Wildlife Fund Canada are acknowledged for their support. R. Togunov is

525 acknowledged for valuable discussions.

526 


\section{References}

ADDISON, R. F. \& BRODIE, P. F. 1973. Occurence of DDT residues in beluga whales (Delphinapterus leucas) from Mackenzie Delta, NWT. Journal of the Fisheries Research Board of Canada, 30, 1733-1736.

ADDISON, R. F. \& SMITH, T. G. 1974. Organochlorine residue levels in Arctic ringed seals variation with age and sex. Oikos, 25, 335-337.

AMAP 1998. AMAP assessment report: Arctic pollution issues, Oslo, Norway, Arctic Monitoring and Assessment Programme (AMAP).

AMAP 2011. Combined effects of selected pollutants and climate change in the Arctic environment. AMAP Technical Report No. 5. Oslo, Norway: Arctic Monitoring and Assessment Programme (AMAP).

AMAP In review. AMAP Assessment report: Chemicals of Emerging Concern. Oslo, Norway: Arctic Monitoring and Assessment Programme (AMAP).

AMSTRUP, S. C. 2000. Polar bear. In: TRUETT, J. J. \& JOHNSON, S. R. (eds.) The Natural History of an Arctic Oil Field: Development and Biota. New York, New York.

AMSTRUP, S. C., MARCOT, B. G. \& DOUGLAS, D. C. 2007. Forecasting the range-wide status of polar bears at selected times in the 21 st century. USGS Science Strategy to Support U.S. Fish and Wildlife Service Polar Bear Listing Decision, U. S. Department of the Interior.

ATWELL, L., HOBSON, K. A. \& WELCH, H. E. 1998. Biomagnification and bioaccumulation of mercury in an arctic marine food web: Insights from stable nitrogen isotope analysis. Canadian Journal of Fisheries and Aquatic Sciences, 55, 1114-1121.

ATWOOD, T. C., MARCOT, B. G., DOUGLAS, D. C., AMSTRUP, S. C., RODE, K. D., DURNER, G. M. \& BROMAGHIN, J. F. 2016. Forecasting the relative influence of environmental and anthropogenic stressors on polar bears. Ecosphere, 7, e01370. 01310.01002/ecs01372.01370.

BARRIE, L. A., GREGOR, D., HARGRAVE, B., LAKE, R., MUIR, D., SHEARER, R., TRACEY, B. \& BIDLEMAN, T. 1992. Arctic contaminants - sources, occurrence and pathways. Science of the Total Environment, 122, 1-74.

BASU, N., SCHEUHAMMER, A. M., SONNE, C., LETCHER, R. J., BORN, E. W. \& DIETZ, R. 2009. Is dietary mercury of neurotoxicological concern to wild polar bears (Ursus maritimus)? Environmental Toxicology and Chemistry, 28, 133-140.

BECHSHOFT, T., DEROCHER, A. E., RICHARDSON, E., LUNN, N. J. \& ST LOUIS, V. L. 2016a. Hair mercury concentrations in western Hudson Bay polar bear family groups. Environmental Science \& Technology, 50, 5313-5319.

BECHSHOFT, T., DEROCHER, A. E., RICHARDSON, E., MISLAN, P., LUNN, N. J., SONNE, C., DIETZ, R., JANZ, D. M. \& LOUIS, V. L. S. 2015. Mercury and cortisol in Western Hudson Bay polar bear hair. Ecotoxicology, 24, 1315-1321.

BECHSHOFT, T., SONNE, C., DIETZ, R., BORN, E. W., MUIR, D. C. G., LETCHER, R. J., NOVAK, M. A., HENCHEY, E., MEYER, J. S., JENSSEN, B. M. \& VILLANGER, G. D. 2012. Associations between complex OHC mixtures and thyroid and cortisol hormone levels in East Greenland polar bears. Environmental Research, 116, 26-35.

BECHSHOFT, T., SONNE, C., JAKOBSEN, J., RIGÉT, F. F., BORN, E. W., LETCHER, R. J., JENSSEN, B. M. \& DIETZ, R. 2016b. Vitamins A and E in liver, kidney, and whole blood of East Greenland polar bears sampled 1994-2008: reference values and temporal trends. Polar Biology, 39, 743-754. 
BECHSHOFT, T., WIIG, O., SONNE, C., RIGET, F. F., DIETZ, R., LETCHER, R. J. \& MUIR, D. C. G. 2008. Temporal and spatial variation in metric asymmetry in skulls of polar bears (Ursus maritimus) from East Greenland and Svalbard. Annales Zoologici Fennici, 45, 15-31.

BECHSHOFT, T. O., RIGÉT, F. F., SONNE, C., DIETZ, R. \& LETCHER, R. J. 2009. Skull foramina asymmetry in East Greenland and Svalbard polar bears (Ursus maritimus) in relation to stressful environments. Annales Zoologici Fennici, 46, 181-192.

BELAND, P., DEGUISE, S., GIRARD, C., LAGACE, A., MARTINEAU, D., MICHAUD, R., MUIR, D. C. G., NORSTROM, R. J., PELLETIER, E., RAY, S. \& SHUGART, L. R. 1993. Toxic compounds and health and reproductive effects in St. Lawrence beluga whales. Journal of Great Lakes Research, 19, 766-775.

BERGMAN, A. 1999. Health condition of the Baltic grey seal (Halichoerus grypus) during two decades - Gynaecological health improvement but increased prevalence of colonic ulcers. Apmis, 107, 270-282.

BERNHOFT, A., SKAARE, J. U., WIIG, O., DEROCHER, A. E. \& LARSEN, H. J. S. 2000. Possible immunotoxic effects of organochlorines in polar bears (Ursus maritimus) at Svalbard. Journal of Toxicology and Environmental Health, 59, 561-574.

BERNHOFT, A., WIIG, O. \& SKAARE, J. U. 1997. Organochlorines in polar bears (Ursus maritimus) at Svalbard. Environmental Pollution, 95, 159-175.

BICKHAM, J. W., SANDHU, S., HEBERT, P. D. N., CHIKHI, L. \& ATHWAL, R. 2000. Effects of chemical contaminants an genetic diversity in natural populations: implications for biomonitoring and ecotoxicology. Mutation Research, 463, 33-51.

BIDLEMAN, T. F., HELM, P. A., BRAUNE, B. M. \& GABRIELSEN, G. W. 2010. Polychlorinated naphthalenes in polar environments - A review. Science of the Total Environment, 408, 2919-2935.

BIGNERT, A., RIGET, F., BRAUNE, B., OUTRIDGE, P. \& WILSON, S. 2004. Recent temporal trend monitoring of mercury in Arctic biota - how powerful are the existing data sets? Journal of Environmental Monitoring, 6, 351-355.

BORN, E. W., RENZONI, A. \& DIETZ, R. 1991. Total mercury in hair of polar bears (Ursus maritimus) from Greenland and Svalbard. Polar Research, 9, 113-120.

BOWES, G. W. \& JONKEL, C. J. 1975. Presence and distribution of polychlorinated biphenyls (PCB) in Arctic and Subarctic marine food chains. Journal of the Fisheries Research Board of Canada, 32, 2111-2123.

BROWN, A. R., HOSKEN, D. J., BALLOUX, F., BICKLEY, L. K., LEPAGE, G., OWEN, S. F., HETHERIDGE, M. J. \& TYLER, C. R. 2009. Genetic variation, inbreeding and chemical exposure - combined effects in wildlife and critical considerations for ecotoxicology. Philosophical Transactions of the Royal Society B, 364, 3377-3390.

BUTT, C. M., BERGER, U., BOSSI, R. \& TOMY, G. T. 2010. Levels and trends of poly- and perfluorinated compounds in the arctic environment. Science of the Total Environment, 408, 2936-2965.

BYTINGSVIK, J., LIE, E., AARS, J., DEROCHER, A. E., WIIG, O. \& JENSSEN, B. M. 2012. PCBs and $\mathrm{OH}-\mathrm{PCB}$ in polar bear mother-cub pairs: a comparative study based on plasma levels in 1998 and 2008. Science of the Total Environment, 417-418, 117-128. CAIRNS, T. \& SIEGMUND, E. G. 1981. PCBs: regulatory history and analytical problems. Analytical Chemistry, 53, 1183A-1193A. 
CATtet, M. R. L., CAulKetT, N. A., OBBARD, M. E. \& STENHOUSE, G. B. 2002. A body condition index for ursids. Canadian Journal of Zoology, 80, 1156-1161.

CHAPMAN, P. M. 2002. Integrating toxicology and ecology: putting the "eco" into ecotoxicology. Marine Pollution Bulletin, 44, 7-15.

CLAUSEN, J., BRAESTRU, L. \& BERG, O. 1974. Content of polychlorinated hydrocarbons in Arctic mammals. Bulletin of Environmental Contamination and Toxicology, 12, 529-534.

CLOTFELTER, E. D., BELL, A. M. \& LEVERING, K. R. 2004. The role of animal behaviour in the study of endocrine-disrupting chemicals. Animal Behaviour, 68, 665-676.

COLBORN, T., SAAL, F. S. V. \& SOTO, A. M. 1993. Developmental effects of endocrinedisrupting chemicals in wildlife and humans. Environmental Health Perspectives, 101, 378-384.

CRAWLEY, M. J. 2007. The R book, Chichester, West Sussex, England, John Wiley \& Sons Ltd.

DE GROOT, P. V., WONG, P. B. Y., HARRIS, C., DYCK, M. G., KAMOOKAK, L., PAGES, M., MICHAUX, J. \& BOAG, P. T. 2013. Toward a non-invasive Inuit polar bear survey: Genetic data from polar bear hair snags. Wildlife Society Bulletin, 37, 394-401.

DEROCHER, A. E., AARS, J., AMSTRUP, S. C., CUTTING, A., LUNN, N. J., MOLNÁR, P. K., OBBARD, M. E., STIRLING, I., THIEMANN, G. W., VONGRAVEN, D., WIIG, Ø. \& YORK, G. 2013. Rapid ecosystem change and polar bear conservation. Conservation Letters, 6, 368-375.

DEROCHER, A. E., ANDERSEN, M. \& WIIG, Ø. 2005. Sexual dimorphism of polar bears. Journal of Mammalogy, 86, 895-901.

DEROCHER, A. E., LUNN, N. J. \& STIRLING, I. 2004. Polar bears in a warming climate. Integrative and Comparative Biology, 44, 163-176.

DEROCHER, A. E., STIRLING, I. \& CALVERT, W. 1997. Male-biased harvesting of polar bears in Western Hudson Bay. Journal of Wildlife Management, 61, 1075-1082.

DEROCHER, A. E., WOLKERS, H., COLBORN, T., SCHLABACH, M., LARSEN, T. S. \& WIIG, Ø. 2003. Contaminants in Svalbard polar bear samples archived since 1967 and possible population level effects. Science of the Total Environment, 301, 163-174.

DIAMANTI-KANDARAKIS, E., BOURGUIGNON, J.-P., GIUDICE, L. C., HAUSER, R., PRINS, G. S., SOTO, A. M., ZOELLER, R. T. \& GORE, A. C. 2009. Endocrinedisrupting chemicals: An Endocrine Society scientific statement. Endocrine Reviews, 30, 293-342.

DIETZ, R., GUSTAVSON, K., SONNE, C., DESFORGES, J. P., RIGET, F. F., PAVLOVA, V., MCKINNEY, M. A. \& LETCHER, R. J. 2015. Physiologically-based pharmacokinetic modelling of immune, reproductive and carcinogenic effects from contaminant exposure in polar bears (Ursus maritimus) across the Arctic. Environmental Research, 140, 45-55.

DIETZ, R., RIGET, F. \& BORN, E. W. 2000. Geographical differences of zinc, cadmium, mercury and selenium in polar bears (Ursus maritimus) from Greenland. Science of the Total Environment, 245, 25-47.

DIETZ, R., RIGET, F. F., SONNE, C., BORN, E. W., BECHSHOFT, T., MCKINNEY, M. A., DRIMMIE, R. J., MUIR, D. C. G. \& LETCHER, R. J. 2013a. Three decades (1983-2010) of contaminant trends in East Greenland polar bears (Ursus maritimus). Part 2: Brominated flame retardants. Environment International, 59, 494-500.

DIETZ, R., RIGET, F. F., SONNE, C., LETCHER, R., BORN, E. W. \& MUIR, D. C. 2004. Seasonal and temporal trends in polychlorinated biphenyls and organochlorine pesticides 
in East Greenland polar bears (Ursus maritimus), 1990-2001. Science of the Total Environment, 331, 107-124.

DIETZ, R., RIGET, F. F., SONNE, C., LETCHER, R. J., BACKUS, S., BORN, E. W., KIRKEGAARD, M. \& MUIR, D. C. 2007. Age and seasonal variability of polybrominated diphenyl ethers in free-ranging East Greenland polar bears (Ursus maritimus). Environmental Pollution, 146, 166-173.

DIETZ, R., SONNE, C., BASU, N., BRAUNE, B., O'HARA, T., LETCHER, R. J., SCHEUHAMMER, T., ANDERSEN, M., ANDREASEN, C., ANDRIASHEK, D., ASMUND, G., AUBAIL, A., BAAGOE, H., BORN, E. W., CHAN, H. M., DEROCHER, A. E., GRANDJEAN, P., KNOTT, K., KIRKEGAARD, M., KREY, A., LUNN, N., MESSIER, F., OBBARD, M., OLSEN, M. T., OSTERTAG, S., PEACOCK, E., RENZONI, A., RIGET, F. F., SKAARE, J. U., STERN, G., STIRLING, I., TAYLOR, M., WIIG, O., WILSON, S. \& AARS, J. 2013b. What are the toxicological effects of mercury in Arctic biota? Science of the Total Environment, 443, 775-790.

DOMINGO, J. L. 1994. Metal-induced developmental toxicity in mammals: A review. Journal of Toxicology and Environmental Health, 42, 123-141.

EATON, R. D. P. \& FARANT, J. P. 1982. The polar bears as a biological indicator of the environmental mercury burden. Arctic, 35, 422-425.

FOLLAND, W. R., NEWSTED, J. L., FITZGERALD, S. D., FUCHSMAN, P. C., BRADLEY, P. W., KERN, J., KANNAN, K., REMINGTON, R. E. \& ZWIERNIK, M. J. 2016. Growth and reproductive effects from dietary exposure to Aroclor 1268 in mink (Neovison vison), a surrogate model for marine mammals. Environmental Toxicology and Chemistry, 35, 604-618.

GABRIELSEN, K. M., KROKSTAD, J. S., OBREGON, M.-J., VILLANGER, G. D., SONNE, C., DIETZ, R. \& JENSSEN, B. M. 2015. Thyroid hormones and deiodinase activities in plasma and tissues from East Greenland polar bears (Ursus maritimus) during winter season. Polar Biology, 38, 1285-1296.

GEBBINK, W. A., BOSSI, R., RIGET, F. F., ROSING-ASVID, A., SONNE, C. \& DIETZ, R. 2016. Observation of emerging per- and polyfluoroalkyl substances (PFASs) in Greenland marine mammals. Chemosphere, 144, 2384-2391.

GIESY, J. P. \& KANNAN, K. 2001. Global distribution of perfluorooctane sulfonate in wildlife. Environmental Science and Technology, 35, 1339-1342.

GRAHAM, M. L., RENNER, V. E. \& BLUKACZ-RICHARDS, E. A. 2013. Ecological risk assessment. In: FÉRARD, J. F. \& BLAISE, C. (eds.) Encyclopedia of Aquatic Ecotoxicology. 1 ed. Dordrecht, Netherlands: Springer.

HAECKEL, E. 1866. Generelle morphologie der organismen, Berlin, Ceorg Riemer.

HAIR, J. F. J., BLACK, W. C., BABIN, B. J., ANDERSON, R. E. \& TATHAM, R. L. 2006. Multivariate data analysis, Upper Saddle RIver, New Jersey 07458, USA, Pearson Education.

HAMLIN, H. J. \& GUILLETTE, L. J., JR. 2011. Embryos as targets of endocrine disrupting contaminants in wildlife. Birth Defects Research Part C, 93, 19-33.

HENRIKSEN, E. O., WIIG, O., SKAARE, J. U., GABRIELSEN, G. W. \& DEROCHER, A. E. 2001. Monitoring PCBs in polar bears: lessons learned from Svalbard. Journal of Environmental Monitoring, 3, 493-498.

HOBSON, K. A., FISK, A., KARNOVSKY, N., HOLST, M., GAGNON, J. M. \& FORTIER, M. 2002. A stable isotope (delta C-13, delta N-15) model for the North Water food web: 

implications for evaluating trophodynamics and the flow of energy and contaminants. Deep-Sea Research Part Ii-Topical Studies in Oceanography, 49, 5131-5150.

HOLDEN, A. V. 1970. Monitoring organochlorine contamination of the marine environment by the analysis of residues in seals. . In: RUIVO, M. (ed.) Marine pollution and sea life. England: Fishing News Books Ltd.

HOLMSTRUP, M., BINDESBOL, A. M., OOSTINGH, G. J., DUSCHL, A., SCHEIL, V., KOHLER, H. R., LOUREIRO, S., SOARES, A. M., FERREIRA, A. L., KIENLE, C., GERHARDT, A., LASKOWSKI, R., KRAMARZ, P. E., BAYLEY, M., SVENDSEN, C. \& SPURGEON, D. J. 2010. Interactions between effects of environmental chemicals and natural stressors: a review. Science of the Total Environment, 408, 3746-3762.

HOOPER, M. J., ANKLEY, G. T., CRISTOL, D. A., MARYOUNG, L. A., NOYES, P. D. \& PINKERTON, K. E. 2013. Interactions between chemical and climate stressors: a role for mechanistic toxicology in assessing climate change risks. Environmental Toxicology and Chemistry, 32, 32-48.

HORTON, T. W., BLUM, J. D., XIE, Z., HREN, M. \& CHAMBERLAIN, C. P. 2009. Stable isotope food-web analysis and mercury biomagnification in polar bears (Ursus maritimus). Polar Research, 28, 443-454.

HUNG, H., KATSOYIANNIS, A. A. \& GUARDANS, R. 2016. Ten years of global monitoring under the Stockholm Convention on Persistent Organic Pollutants (POPs): Trends, sources and transport modelling. Environmental Pollutution, 217, 1-3.

IUCN PBSG 2010. Polar Bears: Proceedings of the 15th Working Meeting of the IUCN/SSC Polar Bear Specialist Group, Copenhagen, Denmark, 29 June-3 July 2009. In: OBBARD, M. E., THIEMANN, G. W., PEACOCK, E. \& DEBRUYN, T. D. (eds.). Gland, Switzerland and Cambridge, UK: IUCN.

IVERSEN, M., AARS, J., HAUG, T., ALSOS, I. G., LYDERSEN, C., BACHMANN, L. \& KOVACS, K. M. 2013. The diet of polar bears (Ursus maritimus) from Svalbard, Norway, inferred from scat analysis. Polar Biology, 36, 561-571.

JENSEN, S. K. 1966. Report of a new chemical hazard. New Scientist, 36, 612.

JENSSEN, B. M., VILLANGER, G. D., GABRIELSEN, K. M., BYTINGSVIK, J., BECHSHØFT, T., CIESIELSKI, T. M., SONNE, C. \& DIETZ, R. 2015. Anthropogenic flank attack on polar bears: interacting conseqiences of climate warming and pollutant exposure. Frontiers in Ecology and the Evolution, 3.

JOHNSON, D. H. 1980. The comparison of usage and availability measurements for evaluating resource preference. Ecology, 61, 65-71.

KEITH, L. H. 1976. Recent advances in the identification and analysis of organic pollutants in water. Life Sciences, 19, 1631-1635.

KERR, R. A. 1979. Global pollution - is the Arctic haze actually industrial smog? Science, 205, 290-293.

KIRKEGAARD, M., SONNE, C., JAKOBSEN, J., JENSSEN, B. M., LETCHER, R. J. \& DIETZ, R. 2010. Organohalogens in a whale-blubber-supplemented diet affects hepatic retinol and renal tocopherol concentrations in greenland sled dogs (Canis familiaris). Journal of Toxicology and Environmental Health, Part A, 73, 773-786.

KNOTT, K. K., BOYD, D., YLITALO, G. M. \& O'HARA, T. M. 2012. Lactational transfer of mercury and polychlorinated biphenyls in polar bears. Chemosphere, 88, 395-402.

KREBS, C. J. 1972. Ecology. The Experimental Analysis of Distribution and Abundance., New York, Harper and Row. 
LETCHER, R. J., BUSTNES, J. O., DIETZ, R., JENSSEN, B. M., JORGENSEN, E. H., SONNE, C., VERREAULT, J., VIJAYAN, M. M. \& GABRIELSEN, G. W. 2010. Exposure and effects assessment of persistent organohalogen contaminants in arctic wildlife and fish. Science of the Total Environment, 408, 2995-3043.

LETCHER, R. J. \& NORSTROM, R. J. 1995. An integrated analytical method for determination of polychlorinated aryl methyl sulfone metabolites and polychlorinated hydrocarbon contaminants in biological matrices. Analytical Chemistry, 67, 4155-4163.

LIE, E., DEROCHER, A. E., WIIG, O. \& SKAARE, J. U. 2000. Polychlorinated biphenyls in mother/offspring pairs of polar bears (Ursus maritimus) at Svalbard. Organohalogen Compounds, 49, 457-460.

LIE, E., LARSEN, H. J. S., LARSEN, S., JOHANSEN, G. M., DEROCHER, A. E., LUNN, N. J., NORSTROM, R. J., WIIG, O. \& SKAARE, J. U. 2005. Does high organochlorine (OC) exposure impair the resistance to infection in polar bears (Ursus maritimus)? Part II: Possible effect of OCs on mitogen- and antigen-induced lymphocyte proliferation. Journal of Toxicology and Environmental Health, Part A, 68, 457-484.

LIE, E., LARSEN, H. J. S., LARSEN, S., JOHNSEN, G. M., DEROCHER, A. E., LUNN, N. J., NORSTROM, R. J., WIIG, O. \& SKAARE, J. U. 2004. Does high organochlorine (OC) exposure impair the resistance to infection in polar bears (Ursus maritimus)? Part I: Effect of OCs on the humoral immunity. Journal of Toxicology and Environmental Health, Part A, 67, 555-582.

MA, J., HUNG, H., TIAN, C. \& KALLENBORN, R. 2011. Revolatilization of persistent organic pollutants in the Arctic induced by climate change. Nature Climate Change, 1, 255-260.

MACBETH, B. J., CATTET, M. R. L., OBBARD, M. E., MIDDEL, K. \& JANZ, D. M. 2012. Evaluation of hair cortisol concentration as a biomarker of long-term stress in freeranging polar bears. Wildlife Society Bulletin, 36, 747-758.

MAEKAWA, F., TSUKAHARA, S., KAWASHIMA, T., NOHARA, K. \& OHKI-HAMAZAKI, H. 2014. The mechanisms underlying sexual differentiation of behavior and physiology in mammals and birds: relative contributions of sex steroids and sex chromosomes. Frontiers in Neuroscience, 8.

MARTIN, P. A., MAYNE, G. J., BURSIAN, S., PALACE, V. \& KANNAN, K. 2006. Changes in thyroid and vitamin A status in mink fed polyhalogenated-aromatic-hydrocarboncontaminated carp from the Saginaw River, Michigan, USA. Environmental Research, 101, 53-67.

MAYOR, S. J., SCHNEIDER, D. C., SCHAEFER, J. A. \& MAHONEY, S. P. 2009. Habitat selection at multiple scales. Ecoscience, 16, 238-247.

MCKINNEY, M. A., ATWOOD, T., DIETZ, R., SONNE, C., RIGET, F., BORN, E. \& PEACOCK, E. 2014. Validation of adipose lipid content as a body condition index for polar bears. Ecology and Evolution, 4, 516-527.

MCKINNEY, M. A., IVERSON, S. J., FISK, A. T., SONNE, C., RIGET, F. F., LETCHER, R. J., ARTS, M. T., BORN, E. W., ROSING-ASVID, A. \& DIETZ, R. 2013. Global change effects on the long-term feeding ecology and contaminant exposures of East Greenland polar bears. Global Change Biology, 19, 2360-2372.

MCKINNEY, M. A., LETCHER, R. J., AARS, J., BORN, E. W., BRANIGAN, M., DIETZ, R., EVANS, T. J., GABRIELSEN, G. W., PEACOCK, E. \& SONNE, C. 2011. Flame retardants and legacy contaminants in polar bears from Alaska, Canada, East Greenland and Svalbard, 2005-2008. Environment International, 37, 365-374. 
MCKINNEY, M. A., PEDRO, S., DIETZ, R., SONNE, C., FISK, A. T., ROY, D., JENSSEN, B. M. \& LETCHER, R. J. 2015. A review of ecological impacts of global climate change on persistent organic pollutant and mercury pathways and exposures in arctic marine ecosystems. Current Zoology, 61, 617-628.

MCKINNEY, M. A., STIRLING, I., LUNN, N. J., PEACOCK, E. \& LETCHER, R. J. 2010. The role of diet on long-term concentration and pattern trends of brominated and chlorinated contaminants in western Hudson Bay polar bears, 1991-2007. Science of the Total Environment, 408, 6210-6222.

MINDELI, L. E. \& MARKUSOVA, V. A. 2015. Bibliometric studies of scientific collaboration: International trends. Automatic Documentation and Mathematical Linguistics, 49, 59-64.

MUIR, D. C. G. \& HOWARD, P. H. 2006. Are there other persistent organic pollutants? A challenge for environmental chemists. Environmental Science \& Technology, 40, 71577166.

NAALAKKERSUISUT. 2005. Executive Order no. 21 of 22 September 2005 on the Protection and Hunting of Polar Bears [Online]. http://lovgivning.gl/lov?rid= \{699D9C77-D0A742D9-B90F-F9F04FA99E3D $\}$. Available: http://lovgivning.gl/lov?rid=\{699D9C77D0A7-42D9-B90F-F9F04FA99E3D [Accessed].

NEWMAN, M. C. 2010. Fundamentals of ecotoxicology, Boca Raton, Florida, CRC Press, Taylor \& Francis Group.

NEWMAN, M. E. 2001. The structure of scientific collaboration networks. PNAS, 98, 404-409.

NORSTROM, R. J., BELIKOV, S. E., BORN, E. W., GARNER, G. W., MALONE, B., OLPINSKI, S., RAMSAY, M. A., SCHLIEBE, S., STIRLING, I., STISHOV, M. S., TAYLOR, M. K. \& WIIG, Ø. 1998. Chlorinated hydrocarbon contaminants in polar bears from Eastern Russia, North America, Greenland, and Svalbard: biomonitoring of Arctic pollution. Archives of Environmental Contamination and Toxicology, 35, 354-367.

NORSTROM, R. J., SCHWEINSBERG, R. E. \& COLLINS, B. T. 1986. Heavy metals and essential elements in livers of the polar bear (Ursus maritimus) in the Canadian Arctic. Science of the Total Environment, 48, 195-212.

NUIJTEN, R. J., HENDRIKS, A. J., JENSSEN, B. M. \& SCHIPPER, A. M. 2016. Circumpolar contaminant concentrations in polar bears (Ursus maritimus) and potential populationlevel effects. Environmental Research, 151, 50-57.

OLSEN, G. H., MAURITZEN, M., DEROCHER, A. E., SORMO, E. G., SKAARE, J. U., WIIG, O. \& JENSSEN, B. M. 2003. Space-use strategy is an important determinant of PCB concentrations in female polar bears in the Barents Sea. Environmental Science and Technology, 37, 4919-4924.

OSKAM, I. C., ROPSTAD, E., DAHL, E., LIE, E., DEROCHER, A. E., WIIG, O., LARSEN, S., WIGER, R. \& SKAARE, J. U. 2003. Organochlorines affect the major androgenic hormone, testosterone, in male polar bears (Ursus maritimus) at Svalbard. Journal of Toxicology and Environmental Health, Part A, 66, 2119-2139.

OSKAM, I. C., ROPSTAD, E., LIE, E., DEROCHER, A. E., WIIG, O., DAHL, E., LARSEN, S. \& SKAARE, J. U. 2004. Organochlorines affect the steroid hormone cortisol in freeranging polar bears (Ursus maritimus) at Svalbard, Norway. Journal of Toxicology and Environmental Health, Part A, 67, 959-977.

Ostertag, S. K., TAGUE, B. A., HUMPHRIES, M. M., TITTLEMIER, S. A. \& CHAN, H. M. 2009. Estimated dietary exposure to fluorinated compounds from traditional foods among Inuit in Nunavut, Canada. Chemosphere, 75, 1165-1172. 
PATISAUL, H. B. \& ADEWALE, H. B. 2009. Long-term effects of environmental endocrine disruptors on reproductive physiology and behavior. Frontiers in Behavioral Neuroscience, 3, 18.

PATYK, K. A., DUNCAN, C., NOL, P., SONNE, C., LAIDRE, K., OBBARD, M., WIIG, Ø., AARS, J., REGEHR, E., GUSTAFSON, L. L. \& ATWOOD, T. 2015. Establishing a definition of polar bear (Ursus maritimus) health: A guide to research and management activities. Science of the Total Environment, 514, 371-378.

PAVLOVA, V., GRIMM, V., DIETZ, R., SONNE, C., VORKAMP, K., RIGET, F. F., LETCHER, R. J., GUSTAVSON, K., DESFORGES, J. P. \& NABE-NIELSEN, J. 2016. Modeling population-level consequences of polychlorinated biphenyl exposure in East Greenland polar bears. Archives of Environmental Contamination and Toxicology, 70, 143-154.

PEDERSEN, K. E., BASU, N., LETCHER, R., GREAVES, A. K., SONNE, C., DIETZ, R. \& STYRISHAVE, B. 2015. Brain region-specific perfluoroalkylated sulfonate (PFSA) and carboxylic acid (PFCA) accumulation and neurochemical biomarker responses in East Greenland polar Bears (Ursus maritimus). Environmental Research, 138, 22-31.

PILSNER, J. R., LAZARUS, A. L., NAM, D. H., LETCHER, R. J., SONNE, C., DIETZ, R. \& BASU, N. 2010. Mercury-associated DNA hypomethylation in polar bear brains via the LUminometric Methylation Assay: a sensitive method to study epigenetics in wildlife. Molecular Ecology, 19, 307-314.

POLISCHUK, S. C., NORSTROM, R. J. \& RAMSAY, M. A. 2002. Body burdens and tissue concentrations of organochlorines in polar bears (Ursus maritimus) vary during seasonal fasts. Environmental Pollution, 118, 29-39.

RATCLIFF, D. A. 1967. Decrease in eggshell weight in certain birds of prey. Nature, 215, 208210.

RATTNER, B. A. 2009. History of wildlife toxicology. Ecotoxicology, 18, 773-783.

REUTERS, T. 2016. Web of Science [Online]. New York, USA. Available: www.webofscience.com [Accessed May 5, 2016].

RIGET, F., BIGNERT, A., BRAUNE, B., STOW, J. \& WILSON, S. 2010. Temporal trends of legacy POPs in Arctic biota, an update. Science of the Total Environment, 408, 28742884.

RIGET, F., BRAUNE, B., BIGNERT, A., WILSON, S., AARS, J., BORN, E., DAM, M., DIETZ, R., EVANS, M., EVANS, T., GAMBERG, M., GANTNER, N., GREEN, N., GUNNLAUGSDOTTIR, H., KANNAN, K., LETCHER, R., MUIR, D., ROACH, P., SONNE, C., STERN, G. \& WIIG, O. 2011. Temporal trends of Hg in Arctic biota, an update. Science of the Total Environment, 409, 3520-3526.

ROBBINS, C. T., BEN-DAVID, M., FORTIN, J. K. \& NELSON, O. L. 2012. Maternal condition determines birth date and growth of newborn bear cubs. Journal of Mammalogy, 93, 540-546.

ROUTTI, H., LETCHER, R. J., BORN, E. W., BRANIGAN, M., DIETZ, R., EVANS, T. J., FISK, A. T., PEACOCK, E. \& SONNE, C. 2011. Spatial and temporal trends of selected trace elements in liver tissue from polar bears (Ursus maritimus) from Alaska, Canada and Greenland. Journal of Environmental Monitoring, 13, 2260-2267.

ROUTTI, H., LETCHER, R. J., BORN, E. W., BRANIGAN, M., DIETZ, R., EVANS, T. J., MCKINNEY, M. A., PEACOCK, E. \& SONNE, C. 2012. Influence of carbon and lipid 
sources on variation of mercury and other trace elements in polar bears (Ursus maritimus). Environmental Toxicology and Chemistry, 31, 2739-2747.

ROUTTI, H., LILLE-LANGØY, R., BERG, M. K., FINK, T., HARJU, M., KRISTIANSEN, K., ROSTKOWSKI, P., RUSTEN, M., SYLTE, I., ØYGARDEN, L. \& GOKSØYR, A. 2016. Environmental chemicals modulate polar bear (Ursus maritimus) peroxisome proliferator-activated receptor gamma (PPARG) and adipogenesis in vitro. Environmental Science \& Technology, 50, 10708-10720.

SACCO, J. C. J., M.O. 2005. Sulfonation of environmental chemicals and their metabolites in the polar bear (Ursus maritimus). Drug Metabolism and Disposition, 33, 1341-1348.

SERGEANT, D. E. \& ARMSTRONG, F. A. 1973. Mercury in seals from eastern Canada. Journal of the Fisheries Research Board of Canada, 30, 843-846.

SIMON, E., BYTINGSVIK, J., JONKER, W., LEONARDS, P. E., DE BOER, J., JENSSEN, B. M., LIE, E., AARS, J., HAMERS, T. \& LAMOREE, M. H. 2011. Blood plasma sample preparation method for the assessment of thyroid hormone-disrupting potency in effectdirected analysis. Environmental Science and Technology, 45, 7936-7944.

SONNE, C. 2010. Health effects from long-range transported contaminants in Arctic top predators: An integrated review based on studies of polar bears and relevant model species. Environment International, 36, 461-491.

SONNE, C., BECHSHOFT, T., RIGET, F. F., BAAGOE, H. J., HEDAYAT, A., ANDERSEN, M., BECH-JENSEN, J. E., HYLDSTRUP, L., LETCHER, R. J. \& DIETZ, R. 2013 a. Size and density of East Greenland polar bear (Ursus maritimus) skulls: Valuable bioindicators of environmental changes? Ecological Indicators, 34, 290-295.

SONNE, C., DIETZ, R., BORN, E. W., RIGET, F. F., KIRKEGAARD, M., HYLDSTRUP, L., LETCHER, R. J. \& MUIR, D. C. G. 2004. Is bone mineral composition disrupted by organochlorines in East Greenland polar bears (Ursus maritimus)? Environmental Health Perspectives, 112, 1711-1716.

SONNE, C., DIETZ, R., BORN, E. W., RIGET, F. F., LEIFSSON, P. S., BECHSHOFT, T. O. \& KIRKEGAARD, M. 2007a. Spatial and temporal variation in size of polar bear (Ursus maritimus) sexual organs and its use in pollution and climate change studies. Science of the Total Environment, 387, 237-246.

SONNE, C., DIETZ, R. \& LETCHER, R. J. 2013b. Chemical cocktail party in East Greenland: A first time evaluation of human organohalogen exposure from consumption of ringed seal and polar bear tissues and possible health implications. Toxicological and Environmental Chemistry, 95, 853-859.

SONNE, C., DYCK, M., RIGET, F. F., BECK JENSEN, J. E., HYLDSTRUP, L., LETCHER, R. J., GUSTAVSON, K., GILBERT, M. T. \& DIETZ, R. 2015. Penile density and globally used chemicals in Canadian and Greenland polar bears. Environmental Research, 137, 287-291.

SONNE, C., GUSTAVSON, K., RIGET, F. F., DIETZ, R., BIRKVED, M., LETCHER, R. J., BOSSI, R., VORKAMP, K., BORN, E. W. \& PETERSEN, G. 2009a. Reproductive performance in East Greenland polar bears (Ursus maritimus) may be affected by organohalogen contaminants as shown by physiologically-based pharmacokinetic (PBPK) modelling. Chemosphere, 77, 1558-1568.

SONNE, C., LETCHER, R. J., BECHSHØFT, T. Ø., RIGÉT, F. F., MUIR, D. C. G., LEIFSSON, P. S., BORN, E. W., HYLDSTRUP, L., BASU, N., KIRKEGAARD, M. \& 
DIETZ, R. 2012. Two decades of biomonitoring polar bear health in Greenland: a review. Acta Veterinaria Scandinavica, 54, S15.

SONNE, C., RIGET, F. F., DIETZ, R., WIIG, O., KIRKEGAARD, M. \& BORN, E. W. 2007b. Skull pathology in East Greenland and Svalbard polar bears (Ursus maritimus) during 1892 to 2002 in relation to organochlorine pollution. Science of the Total Environment, 372, 554-561.

SONNE, C., WOLKERS, H., LEIFSSON, P. S., IBURG, T., JENSSEN, B. M., FUGLEI, E., AHLSTROM, O., DIETZ, R., KIRKEGAARD, M., MUIR, D. C. \& JORGENSEN, E. H. 2009b. Chronic dietary exposure to environmental organochlorine contaminants induces thyroid gland lesions in Arctic foxes (Vulpes lagopus). Environmental Research, 109, 702-711.

ST LOUIS, V. L., DEROCHER, A. E., STIRLING, I., GRAYDON, J. A., LEE, C., JOCKSCH, E., RICHARDSON, E., GHORPADE, S., KWAN, A. K., KIRK, J. L., LEHNHERR, I. \& SWANSON, H. K. 2011. Differences in mercury bioaccumulation between polar bears (Ursus maritimus) from the Canadian high- and sub-Arctic. Environmental Science \& Technology, 45, 5922-5928.

STIRLING, I. 2002. Polar bears and seals in the eastern Beaufort Sea and Amundsen Gulf: A synthesis of population trends and ecological relationships over three decades. Arctic, 55, 59-76.

STIRLING, I. \& DEROCHER, A. E. 2012. Effects of climate warming on polar bears: a review of the evidence. Global Change Biology, 18, 2694-2706.

STIRLING, I., THIEMANN, G. W. \& RICHARDSON, E. 2008. Quantitative support for a subjective fatness index for immobilized polar bears. Journal of Wildlife Management, 72, 568-574.

SUBRAMANYAM, K. 1983. Bibliometric studies of research collaboration: A review. Journal of Information Science, 6, 33-38.

TAYLOR, M. K., LAAKE, J., MCLOUGHLIN, P. D., CLUFF, H. D. \& MESSIER, F. 2006. Demographic parameters and harvest-explicit population viability analysis for polar bears in M'Clintock Channel, Nunavut, Canada. Journal of Wildlife Management, 70, 16671673.

THIEMANN, G. W., IVERSON, S. J. \& STIRLING, I. 2008. Polar bear diets and Arctic marine food webs: insights from fatty acid analysis. Ecological Monographs, 78, 591-613.

TRUMBLE, S. J., ROBINSON, E. M., NOREN, S. R., USENKO, S., DAVIS, J. \& KANATOUS, S. B. 2012. Assessment of legacy and emerging persistent organic pollutants in Weddell seal tissue (Leptonychotes weddellii) near McMurdo Sound, Antarctica. Science of the Total Environment, 439, 275-283.

UNEP. 2001. The Stockholm Convention [Online]. Available: http://chm.pops.int/TheConvention/Overview/tabid/3351/Default.aspx [Accessed May 2, 2016].

VAN GINNEKEN, V., PALSTRA, A., LEONARDS, P., NIEVEEN, M., VAN DEN BERG, H., FLIK, G., SPANINGS, T., NIEMANTSVERDRIET, P., VAN DEN THILLART, G. \& MURK, A. 2009. PCBs and the energy cost of migration in the European eel (Anguilla anguilla L.). Aquatic Toxicology, 92, 213-220.

VERREAULT, J., BECH, C., LETCHER, R. J., ROPSTAD, E., DAHL, E. \& GABRIELSEN, G. W. 2007. Organohalogen contamination in breeding glaucous gulls from the 
Norwegian Arctic: Associations with basal metabolism and circulating thyroid hormones. Environmental Pollution, 145, 138-145.

VERREAULT, J., NORSTROM, R. J., RAMSAY, M. A., MULVIHILL, M. \& LETCHER, R. J. 2006. Composition of chlorinated hydrocarbon contaminants among major adipose tissue depots of polar bears (Ursus maritimus) from the Canadian high Arctic. Science of the Total Environment, 370, 580-587.

VILLANGER, G. D., JENSSEN, B. M., FJELDBERG, R. R., LETCHER, R. J., MUIR, D. C. G., KIRKEGAARD, M., SONNE, C. \& DIETZ, R. 2011. Exposure to mixtures of organohalogen contaminants and associative interactions with thyroid hormones in East Greenland polar bears (Ursus maritimus). Environment International, 37, 694-708.

VOLTURA, M. B. \& FRENCH, J. B. J. 2000. Effects of dietary polychlorinated biphenyl exposure on energetics of white-footed mouse, Peromyscus leucopus. Environmental Toxicology and Chemistry, 19, 2757-2761.

VONGRAVEN, D., AARS, J., AMSTRUP, S. C., ATKINSON, S. N., BELIKOV, S. E., BORN, E. W., DEBRUYN, T. D., DEROCHER, A. E., DURNER, G. M., GILL, M., LUNN, N., OBBARD, M. E., OMELAK, J., OVSYANIKOV, N., PEACOCK, E., RICHARDSON, E., SAHANATIEN, V., STIRLING, I. \& WIIG, Ø. 2012. A circumpolar monitoring framework for polar bears. Ursus Monographs, 5, 1-66.

WANG, W., EVANS, R. D., HICKIE, B. E., ROUVINEN-WATT, K. \& EVANS, H. E. 2014. Methylmercury accumulation and elimination in mink (Neovison vison) hair and blood: results of a controlled feeding experiment using stable isotope tracers. Environmental Toxicology and Chemistry, 33, 2873-2880.

WARNER, N. A., EVENSET, A., CHRISTENSEN, G., GABRIELSEN, G. W., BORGA, K. \& LEKNES, H. 2010. Volatile siloxanes in the European Arctic: Assessment of sources and spatial distribution. Environmental Science \& Technology, 44, 7705-7710.

WEISSER, J. J., HANSEN, M., BJORKLUND, E., SONNE, C., DIETZ, R. \& STYRISHAVE, B. 2016. A novel method for analysing key corticosteroids in polar bear (Ursus maritimus) hair using liquid chromatography tandem mass spectrometry. Journal of Chromatography B, 1017-1018, 45-51.

WIENER, J. G. 2013. Mercury exposed: advances in environmental analysis and ecotoxicology of a highly toxic metal. Environmental Toxicology and Chemistry, 32, 2175-2178.

ZIMMER, K. E., GUTLEB, A. C., LYCHE, J. L., DAHL, E., OSKAM, I. C., KROGENAES, A., SKAARE, J. U. \& ROPSTAD, E. 2009. Altered stress-induced cortisol levels in goats exposed to polychlorinated biphenyls (PCB 126 and PCB 153) during fetal and postnatal development. Journal of Toxicology and Environmental Health, Part A, 72, 164-172. 
1019 Tables

1020

1021 Table 1. Core ecological variables included in the present systematic review of polar bear 1022 toxicology literature. The full list of all variables and their definitions can be found under 1023 Supporting information (Table S2).

1024

1025 Table 2. Authorship by country of the 207 papers included in the present systematic review of

1026 the status of polar bear toxicology literature; 31 reviews and 180 research papers (four

1027 publications were in both categories, see text for details).

1028

1029 Table 3. Biological (physiological and morphological) variables investigated in relation to 1030 contaminants in the research papers included in the present systematic review of polar bear 1031 toxicology literature. The table is based on 66 papers, some of which analyzed multiple of the 1032 listed variables.

1033

1034 Table 4. Recommendation for focal polar bear subpopulations for future ecotoxicology research 1035 based on their respective strengths with regard to available data. 


\section{$1037 \quad$ Figure legends}

1038

1039

1040

Fig. 1. Frequency of polar bear focused toxicological papers $(n=207)$ based on the year of publication and categorized by type (i.e. review or research) included in the systematic review.

1041

1042 Fig. 2. Index of toxicology publications for a selection of marine and terrestrial mammal species

1043 relative to those published for polar bears. The index was created using the raw, unfiltered results

1044 from literature searches for each species in connection with the contaminant-related search terms

1045 outlined in the text. The dashed line represents the polar bear, here a value of 1 on the index

1046 scale.

1047

1048 Fig. 3a-b. The number of authors on the papers included in the present systematic review of the

1049 status of polar bear toxicology literature for: a) review papers, 1992-2016, b) research papers, 1050 1970-2016.

1051

1052 Fig. 4a. Map indicating the 19 currently recognized polar bear subpopulations (map from IUCN

1053 PBSG). GB: Gulf of Boothia, KB: Kane Basin, LS: Lancaster Sound, MC: M'Clintock Channel,

1054 NB: Northern Beaufort Sea, NW: Norwegian Bay, SB: Southern Beaufort Sea, VM: Viscount

1055 Melville Sound, WH: Western Hudson Bay.

1056

1057 Fig. 4b. Number of times each of 19 polar bear subpopulations were incorporated in 1058 toxicological research papers $(n=180)$. 
1060 Fig. 5. Sample size (individual bears) in polar bear toxicology research papers $(\mathrm{n}=180)$, as 1061 included in the present systematic review, published over the investigated period (1970-2016).

1063 Fig. 6. Percentage of published polar bear toxicology research papers $(n=180)$ in relation to 1064 type of tissue(s) analyzed. As more than one tissue type may have been analyzed in a single 1065 paper, the combined percentages of all tissue types could exceed $100 \%$.

1066

1067 Fig. 7. Percentage of published polar bear toxicology research papers $(n=180)$ in relation to year 1068 of sample collection. As more than one year bin may have been covered in a single paper, the 1069 combined percentages of all year bins could exceed $100 \%$.

1071 Fig. 8. Percentage of published polar bear toxicology research papers $(n=180)$ in relation to 1072 contaminant groups studied. As more than one contaminant group may have been analyzed in a 1073 single paper, the combined percentages of all contaminant groups could exceed $100 \%$.

1075 Fig. 9. Percentage of published polar bear toxicology research papers $(\mathrm{n}=180)$ in relation to 1076 contaminant-related issues studied. B: Biological (here: sex and/or age), C: Contaminant

1077 concentration(s), S: Spatial issues, T: Temporal issues, O: Other 


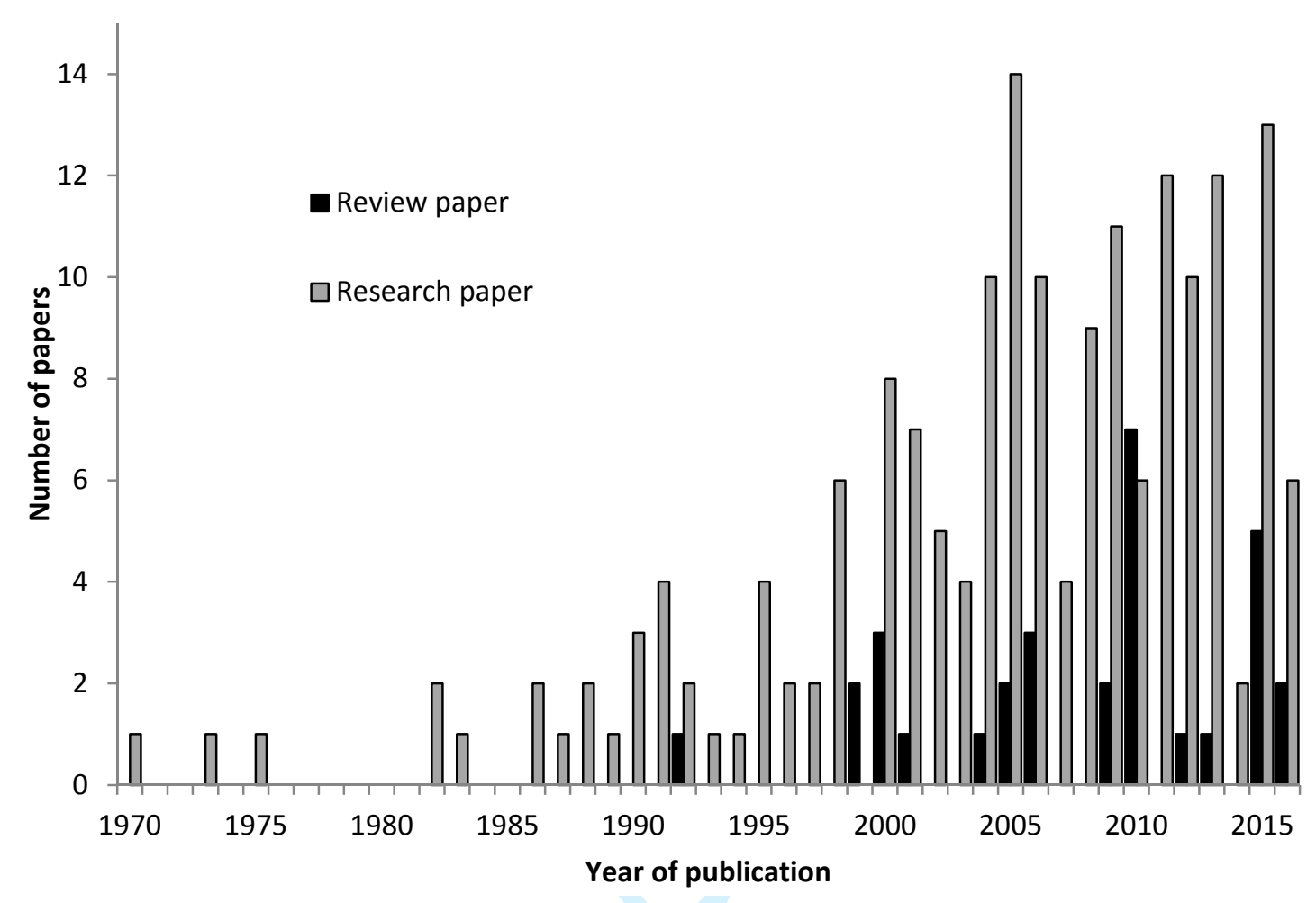

Fig. 1. 


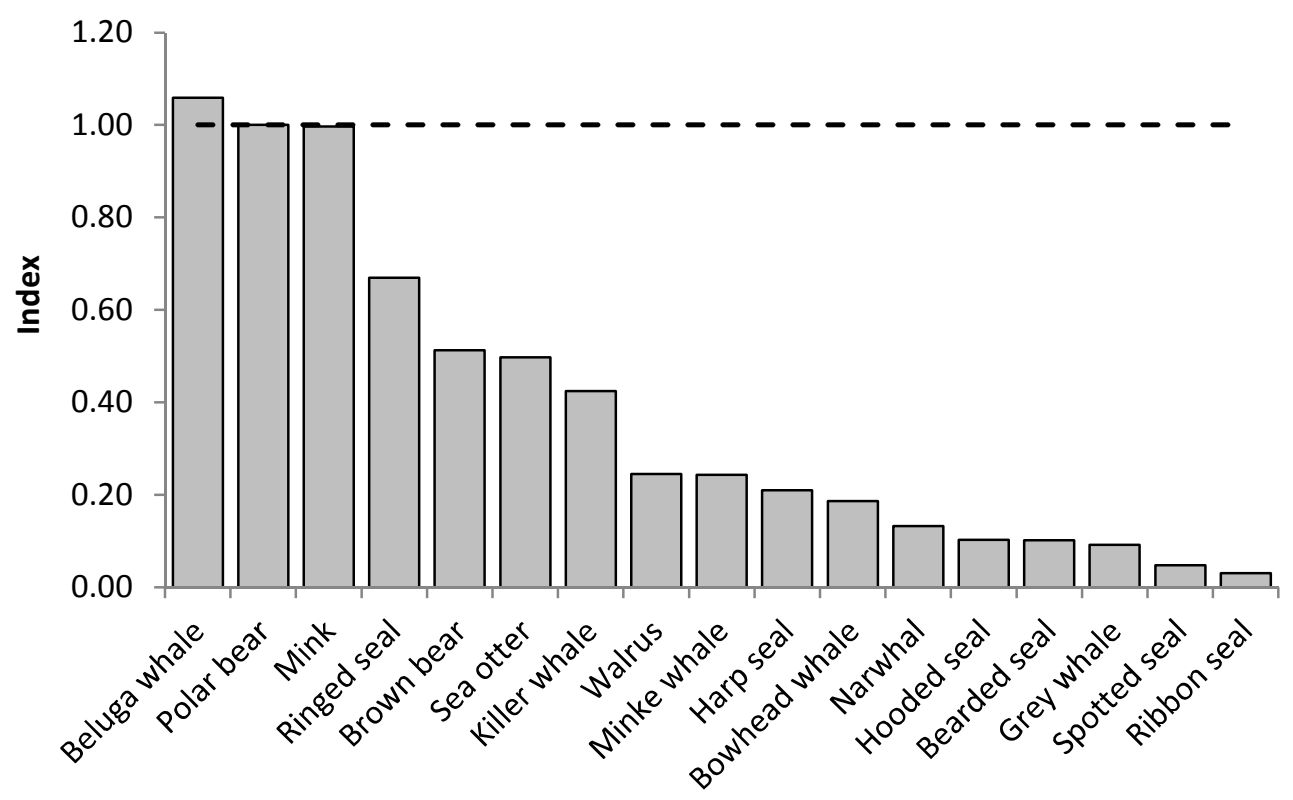

Fig. 2. 
a)

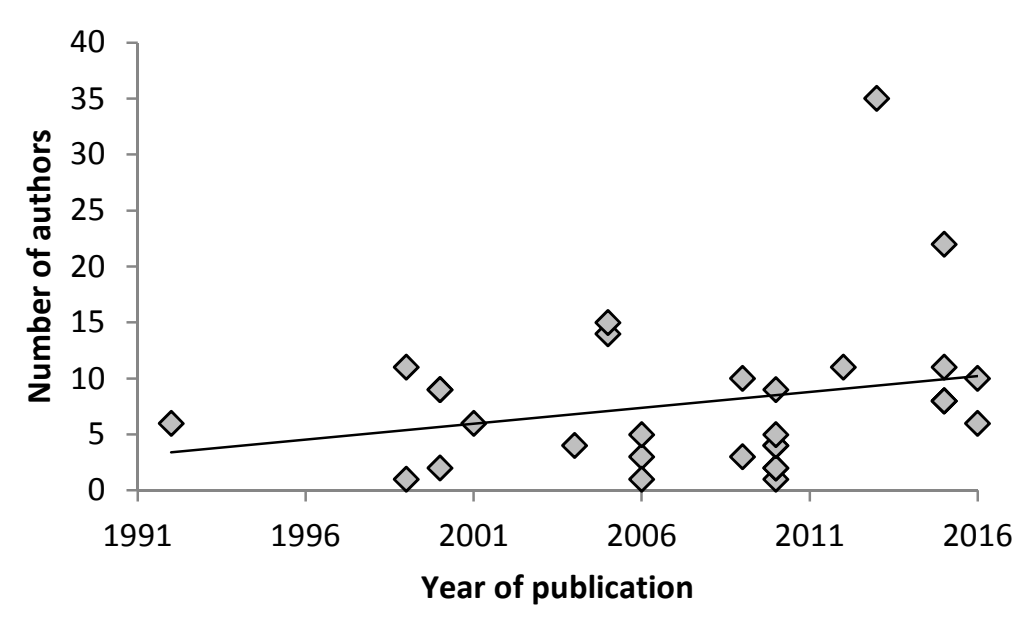

b)

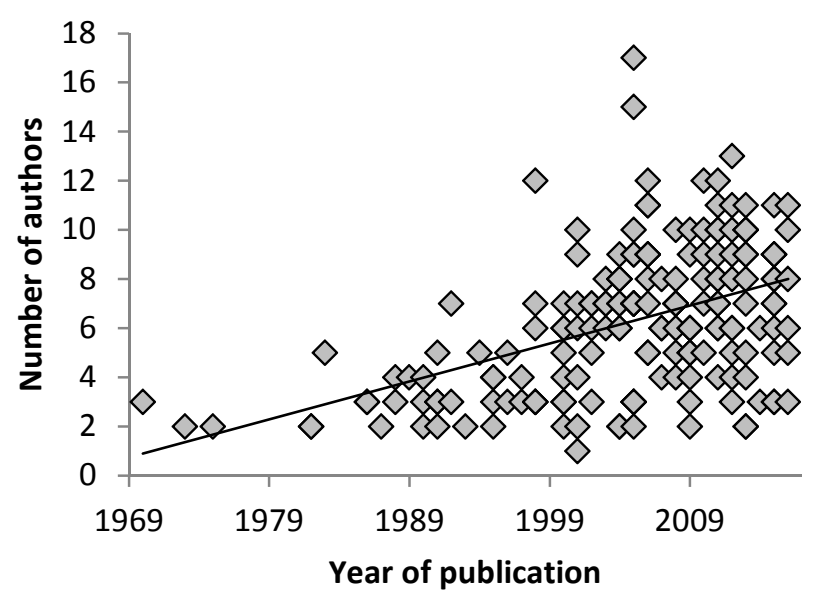

Fig. 3a-b. 


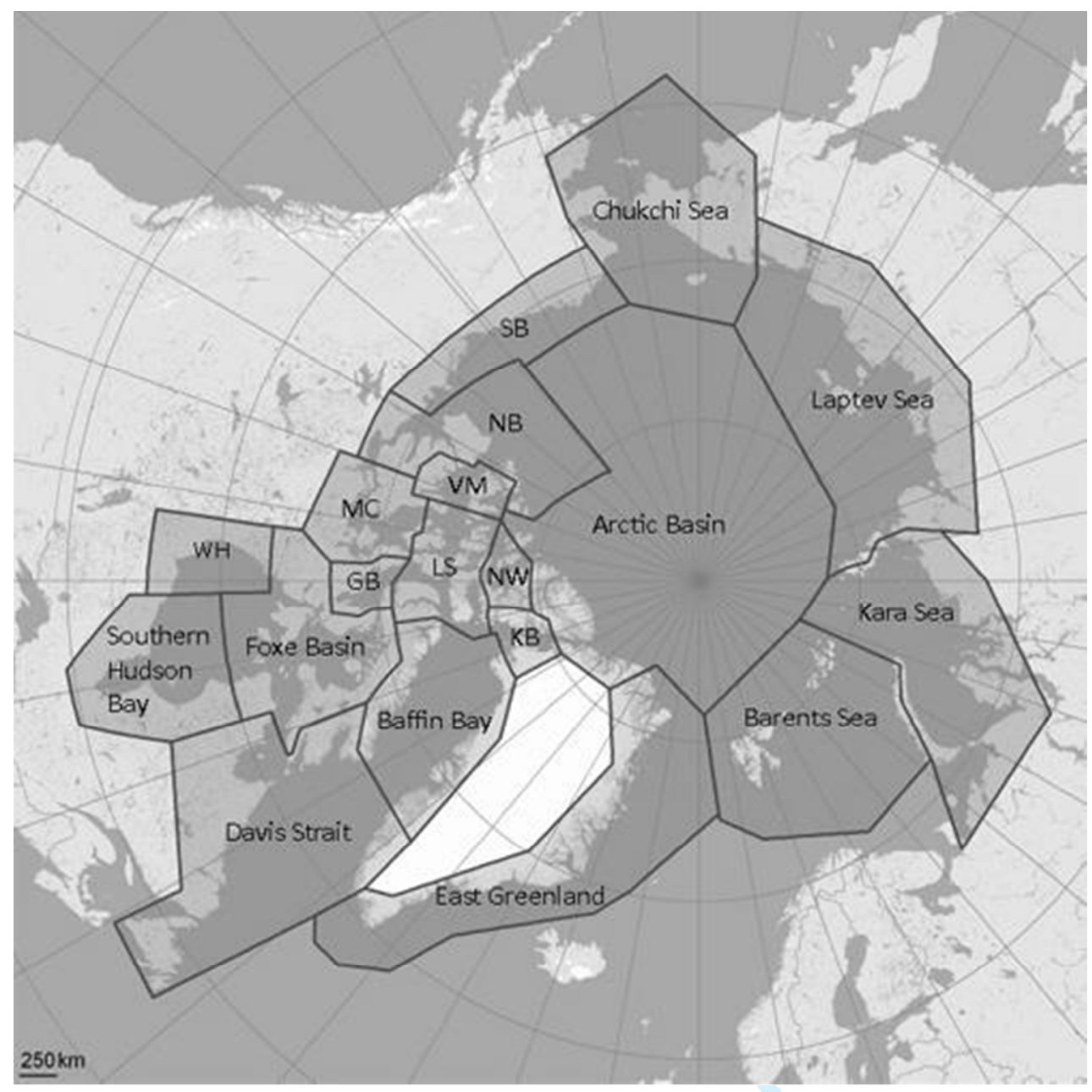

Fig. 4a. 


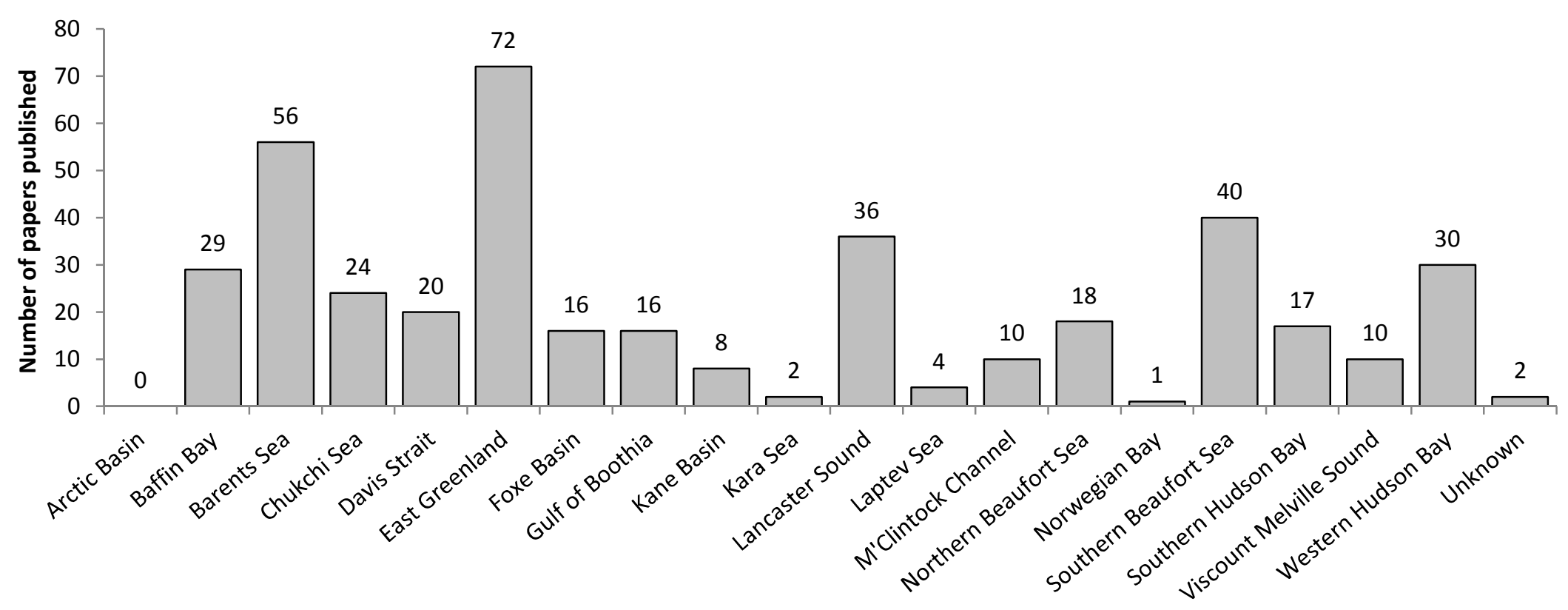

Fig. 4b. 


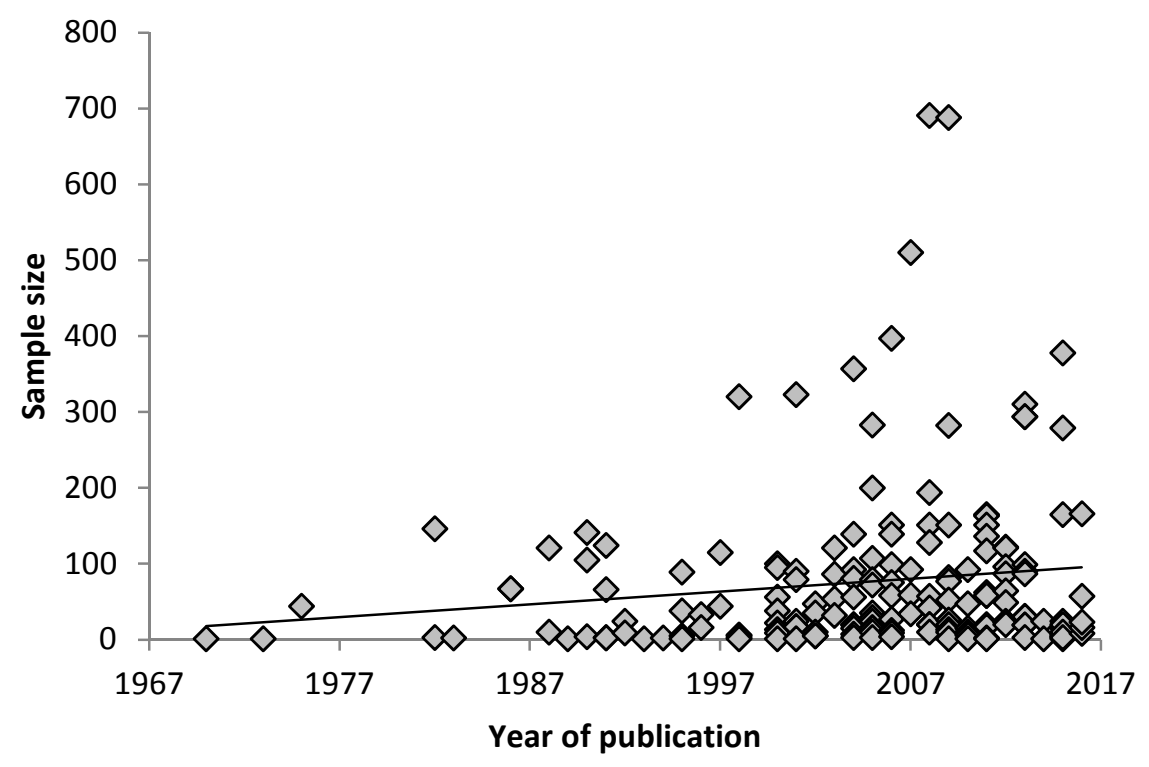

Fig. 5 


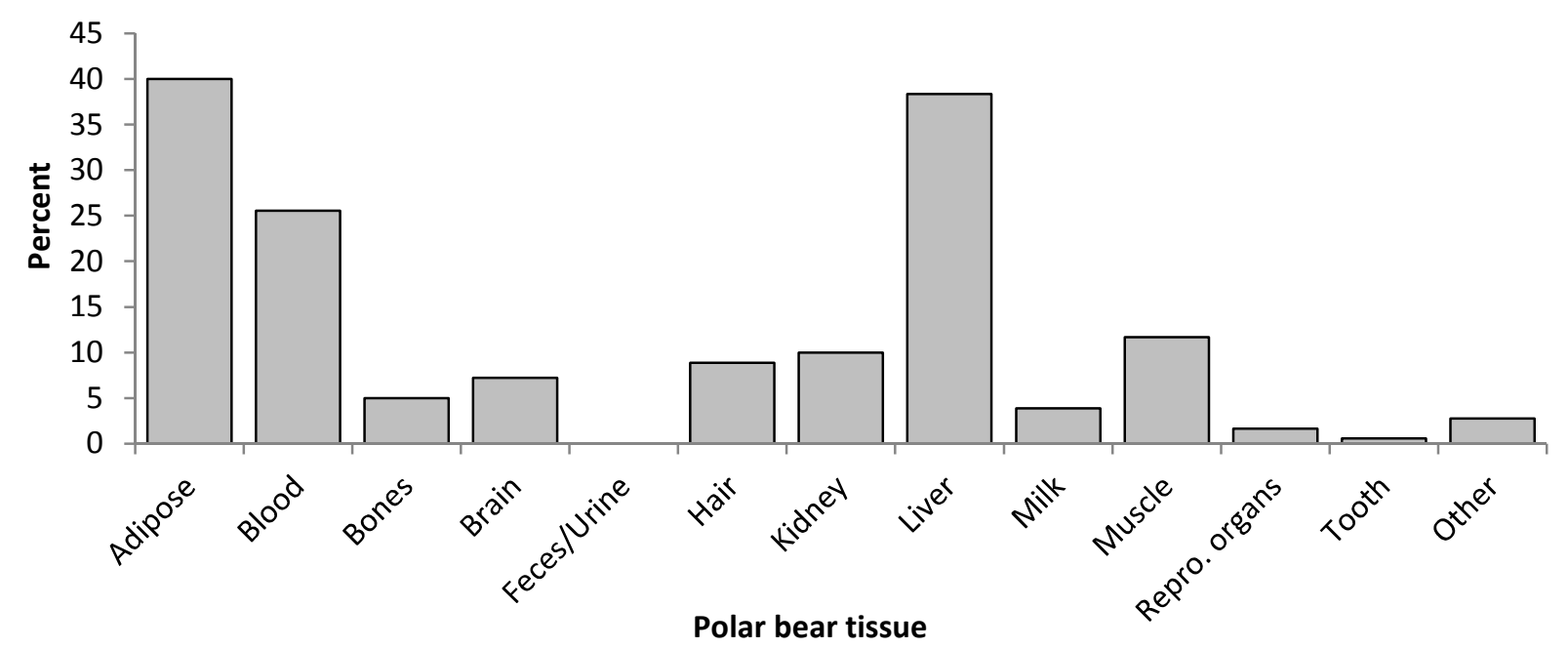

Fig. 6. 


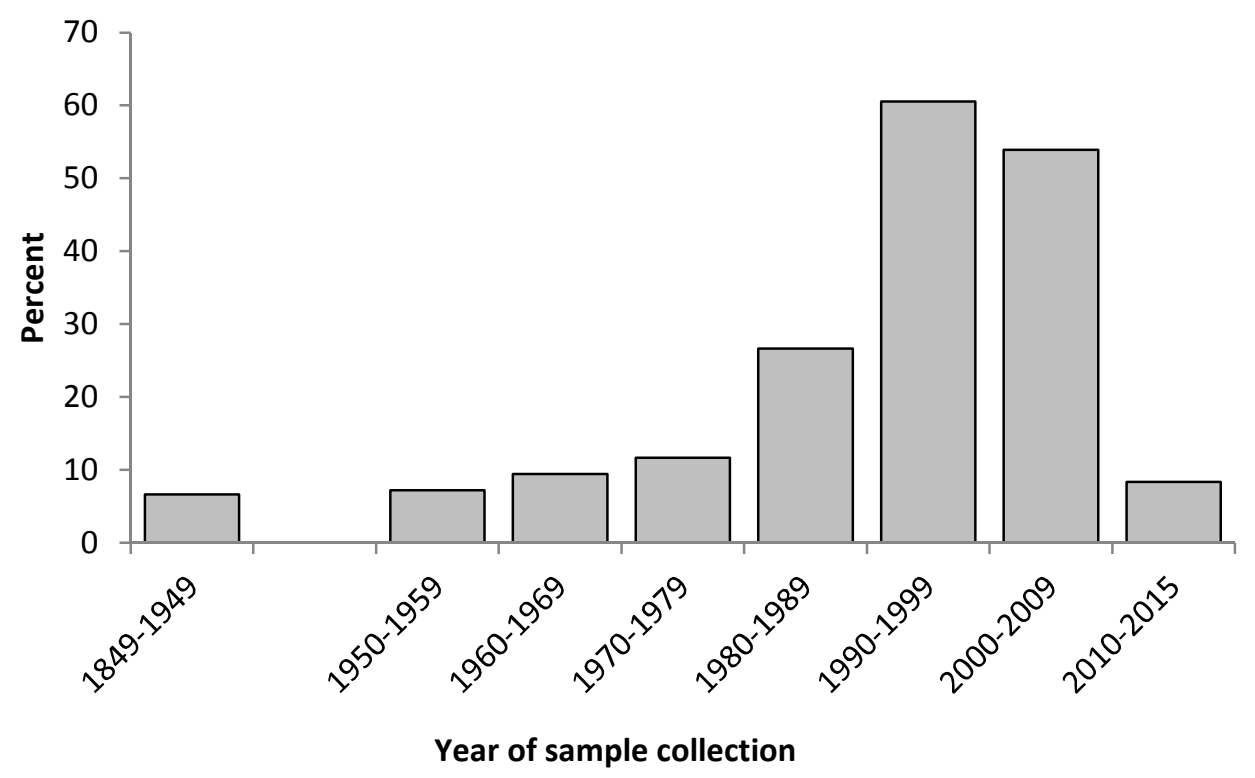

Fig. 7. 


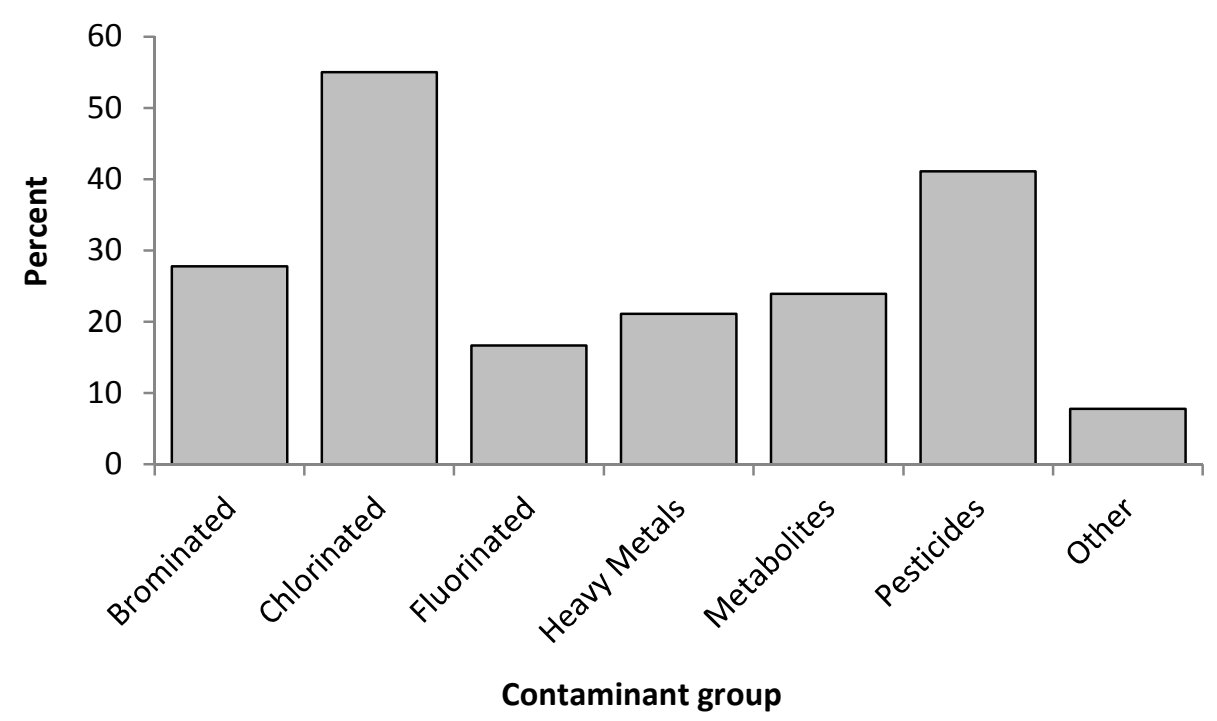

Fig. 8. 


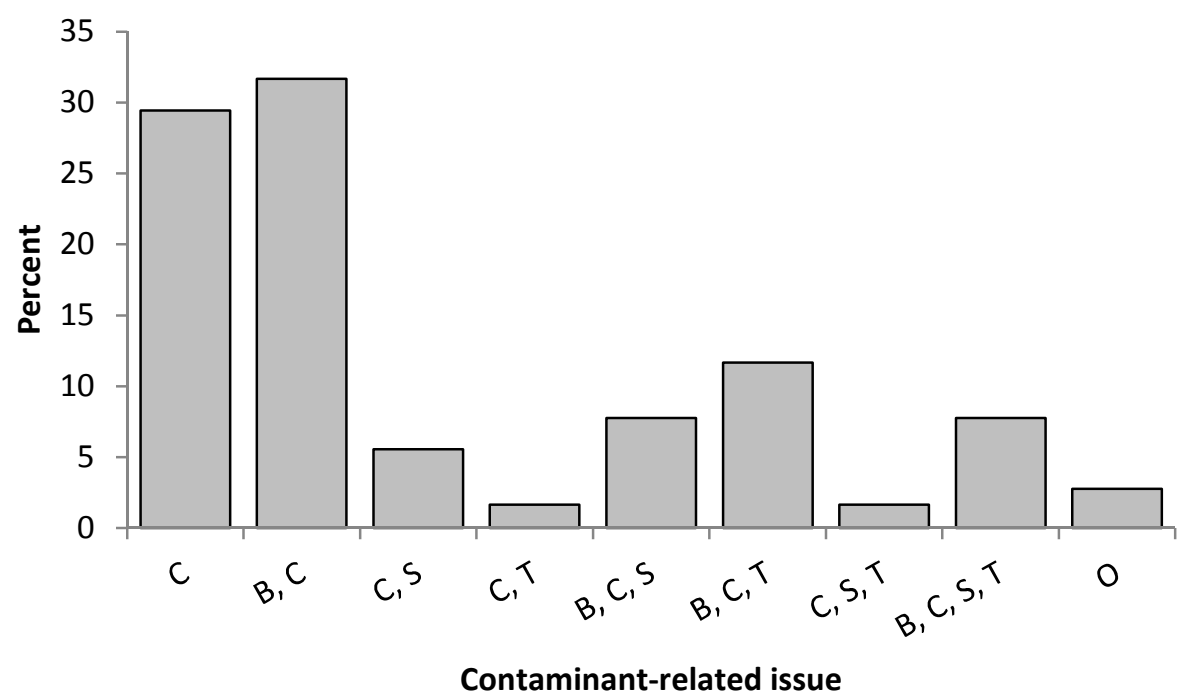

Fig. 9. 


\begin{tabular}{|c|c|c|}
\hline $\begin{array}{l}\text { Ecological variables included in the contaminant analysis in } \\
\text { the } 180 \text { analyzed research papers }\end{array}$ & Number & Percent \\
\hline \multicolumn{3}{|l|}{ Age } \\
\hline - Specific age (months/years) & 148 & 82 \\
\hline \multicolumn{3}{|l|}{ Class } \\
\hline - Cub-of-the-year & 24 & 13 \\
\hline - Yearling & 36 & 20 \\
\hline - Subadult & 102 & 57 \\
\hline - Adult & 142 & 79 \\
\hline - Unknown & 25 & 14 \\
\hline Behavior & 0 & 0 \\
\hline Body condition (any metric) & 46 & 26 \\
\hline \multicolumn{3}{|l|}{ Climate } \\
\hline - Climate index & 1 & $<1$ \\
\hline - Season & 1 & $<1$ \\
\hline - Temperature & 1 & $<1$ \\
\hline \multicolumn{3}{|l|}{ Diet } \\
\hline - Fatty acid & 6 & 3 \\
\hline - Stable isotopes & 17 & 9 \\
\hline Genetics & 2 & 1 \\
\hline Home range size (movement) & 2 & 1 \\
\hline Reproductive history & 21 & 12 \\
\hline \multicolumn{3}{|l|}{ Offspring } \\
\hline - Litter size & 4 & 2 \\
\hline - Sex & 7 & 4 \\
\hline - Age & 16 & 9 \\
\hline \multicolumn{3}{|l|}{ Sex } \\
\hline - Male & 130 & 72 \\
\hline - Female & 134 & 74 \\
\hline - Unknown & 43 & 24 \\
\hline
\end{tabular}

Table 1. 


\begin{tabular}{|l|c|c|c|c|}
\cline { 2 - 5 } \multicolumn{1}{c|}{} & \multicolumn{2}{l|}{ Review paper } & \multicolumn{2}{l|}{ Research paper } \\
\hline Authorship & $\begin{array}{l}\text { First } \\
\text { author }\end{array}$ & Coauthor & $\begin{array}{l}\text { First } \\
\text { author }\end{array}$ & Coauthor \\
\hline Canada & 9 & 19 & 60 & 104 \\
\hline Denmark & 10 & 9 & 43 & 70 \\
\hline Greenland & 0 & 1 & 1 & 22 \\
\hline Norway & 4 & 8 & 34 & 59 \\
\hline Russia & 0 & 0 & 0 & 12 \\
\hline US & 5 & 7 & 24 & 45 \\
\hline Other & 3 & 7 & 18 & 31 \\
\hline
\end{tabular}

Table 2 


\begin{tabular}{|l|c|c|}
\hline Variable & Number & Percent \\
\hline Enzymes & 9 & 5 \\
\hline $\begin{array}{l}\text { Hormones } \\
\text { - Steroid } \\
\bullet \quad \text { Thyroid }\end{array}$ & 11 & 6 \\
\hline Immune system & 10 & 6 \\
\hline Morphometrics & 4 & 2 \\
\hline Other & 7 & 4 \\
\hline Parasites/zoonosis & 3 & 2 \\
\hline Pathology & 0 & 0 \\
\hline Protein levels & 17 & 9 \\
\hline Receptor levels & 4 & 2 \\
\hline Reproductive effects & 5 & 3 \\
\hline$\quad$ Litter size & 0 & \\
• Potential & 4 & 2 \\
\hline Transport proteins & 5 & 3 \\
\hline Vitamins & 4 & 2 \\
\hline
\end{tabular}

Table 3. 


\begin{tabular}{|c|c|c|c|c|c|c|}
\hline \\
\hline & & 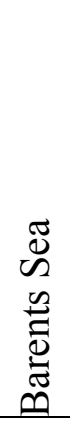 & $\begin{array}{l}\mathscr{E} \\
\mathscr{A} \\
\cdot \Xi \\
0 \\
\frac{y}{\Xi} \\
己\end{array}$ & 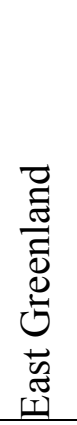 & 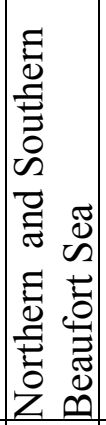 & 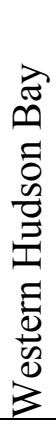 \\
\hline \multirow{2}{*}{ Data available on } & life history (e.g., fatness, tooth wear) & $\mathrm{X}$ & $\mathrm{X}$ & & $\mathrm{X}$ & $\mathrm{X}$ \\
\hline & family groups & $\mathrm{X}$ & $\mathrm{X}$ & & $\mathrm{X}$ & $\mathrm{X}$ \\
\hline \multirow{3}{*}{ Samples available } & maximally invasive (e.g., inner organs) & & & $\mathrm{X}$ & & \\
\hline & high number/consistent sampling efforts & $\mathrm{X}$ & $\mathrm{X}$ & $\mathrm{X}$ & $\mathrm{X}$ & $\mathrm{X}$ \\
\hline & $\begin{array}{l}\text { potential repeat captures and sampling } \\
\text { of the same individual }\end{array}$ & $\mathrm{X}$ & $\mathrm{X}$ & & $X$ & $X$ \\
\hline \multirow[b]{2}{*}{ Contaminant } & high concentrations & $\mathrm{X}$ & & $\mathrm{X}$ & $X$ & \\
\hline & $\begin{array}{l}\text { previously investigated (i.e. potential for } \\
\text { investigating temporal trends) }\end{array}$ & $\mathrm{X}$ & & $X$ & $\mathrm{X}$ & $X$ \\
\hline
\end{tabular}

Table 4. 